\title{
COMPARISON OF SELECTED RIVET AND RIVETING INSTRUCTIONS
}

\author{
Jerzy Kaniowski \\ Institute of Aviation, Al. Krakowska 110/114, 02-256 Warsaw, Poland \\ jerzy.kaniowski@ilot.edu.pl
}

\begin{abstract}
Sheet metal parts are widely used in airframes. Most sheet metal parts used in aircraft assembly are joined using rivets. A number of riveting parameters directly influence fatigue properties of a structure. These include a rivet length, driven head diameter, tolerance of a rivet hole and a rivet shank diameter, and a protective layer among others. Unfavourable selection or change of these parameters can lead to stress concentrations and early crack nucleation. Crack growth can cause failure of a whole structure.

The selection of the riveting process parameters is usually described in a company's internal instruction (process specifications). Some parameters can be defined in an aircraft's technical specifications. Riveting instructions among other production documentation are part of a company's closely guarded know-how. The author obtained access to two riveting instructions used in Poland and three such documents used in western Europe. The author was permitted to publish the comparison of the parameters from these documents but he is not supposed to reveal any other information. For the reasons stated above, the following cryptonyms were used in the article: Poland-1, Poland-2, West-1, West-2 and West-3.

The quality of a joint also depends on rivets parameters that are defined in rivets standards. For this reason, selected rivets defined in the Polish and Russian industry standards as well as western standards are compared in this paper. Tolerances of a rivet and a hole diameter, clearances between a rivet and a hole, rivet lengths anticipated for driven head formation as well as driven head dimensions are taken into account.
\end{abstract}

Keywords: Riveted joints, rivets, riveting parameters, riveting instructions and standards

\section{INTRODUCTION}

'The riveting is ... the basic type of inseparable joint used in manufacturing of structure made of light alloys. Riveting especially wide application has find in aircraft design' - quotation from [1]. Much of the data from this book, published in 1954, appear in the Polish industry standards and the Poland-1 instruction.

Sheet metal parts are widely used in airframes. Most sheet metal parts used in aircraft assembly are joined using rivets. On multiple occasions, fatigue damages of riveted joints were found to be the cause of plane crashes. Since a plane crash usually entails loss of lives and serious economical losses, riveted joints should continue to be investigated intensively.

Numerous riveting parameters e.g. a rivet length, driven head diameter, tolerance of rivet hole and rivet shank diameter, and a protective layer, have a direct impact on fatigue properties of airframes. Unfavourable selection or change of these parameters can lead to stress concentration and early crack nucleation. Crack growth can cause failure of a whole structure. 
Basic principles for the selection of the rivet diameter, countersunk depth, driven head dimension and recommended operation during riveting are given in free access documents [2].

Scientific papers, doctoral theses and reports provide only fragmentary information about technologies involved in the riveted joints assembly. Muller [3] and Rans [4] emphasised that the instruction from the BAe, Fokker and MBB companies recommend that portion of the countersunk hole with at least $0.2 \div 0.1 \mathrm{~mm}$ height remain cylindrical. Rijk [5] states that a hole diameter should be $0.1 \mathrm{~mm}$ larger than a rivet diameter.

The selection of the riveting process parameters is usually described in a company's internal instructions (process specifications). Some parameters can be defined in an aircraft's technical specification. Riveting instructions together with other production documentation are part of a company's closely guarded know-how. The author obtained access to two riveting instructions used in Poland and three such documents used in Western Europe. The author was allowed to publish the comparison of the parameters included in these documents but he cannot reveal any other information. For the reasons stated above, the following cryptonyms were used in the article: Poland-1, Poland-2, West-1, West-2 and West-3.

The quality of a joint also depends on rivet parameters defined in rivet standards. This is the reason that the selected rivets defined in the Polish industry standards and western standards will be compared in this paper.

\section{RIVETS}

The characteristics of rivets defined in the selected standards will be compared. The rivets were presented in Figures 1 to 4 . They are defined in the Polish industry and national standards, Russian industry standards and western standards.

\section{Manufacturing tolerances and rivets geometry}

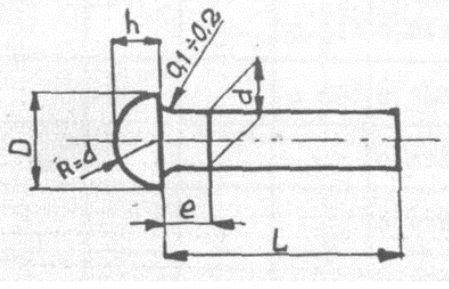

$a$

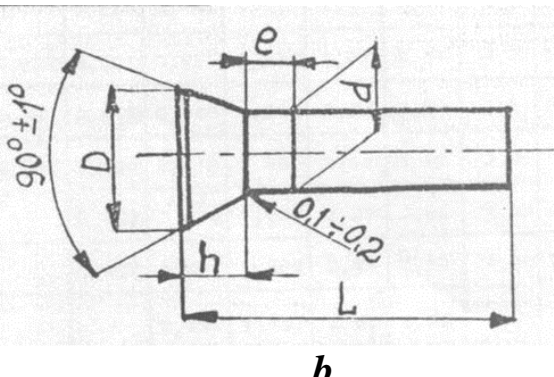

$b$

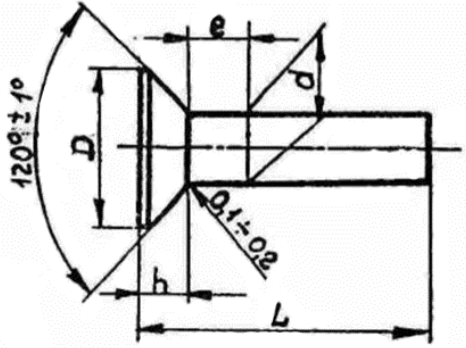

c

Fig. 1. Polish industry standards - rivets: a) round BN-70/1121-03, b) 90 countersunk BN-70/1121-04, c) 120 countersunk BN-70/1121-05; [7].

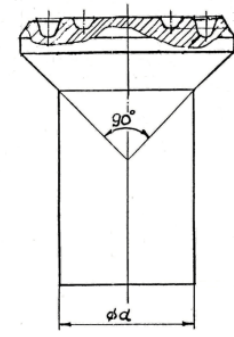

$\boldsymbol{a}$

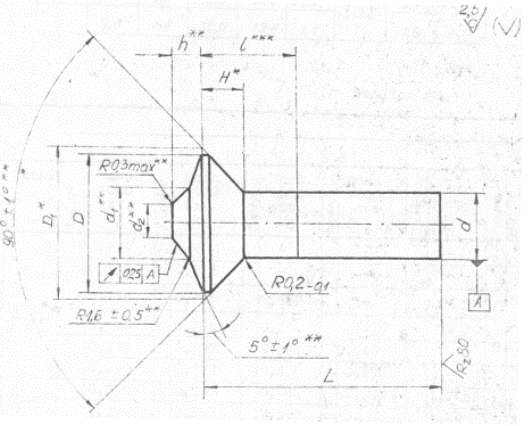

$b$

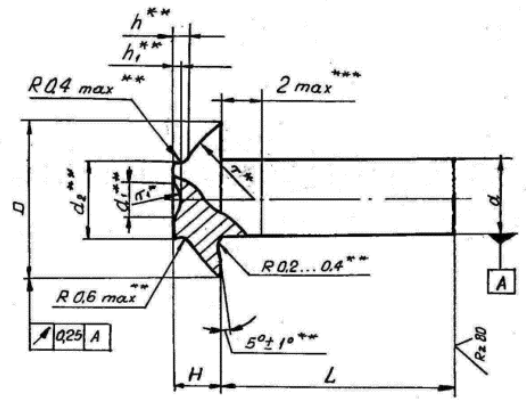

c

Fig. 2. Russian standards - rivets with a compensator: a) $90^{\circ}$ countersunk ANU 0301 [9], b) 90 countersunk OST 1 12020-75 [10], c) brazier OST 1 34040-79 [8]. 


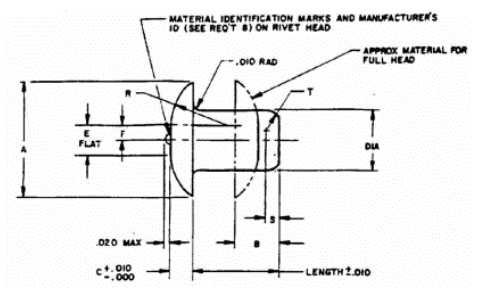

$a$

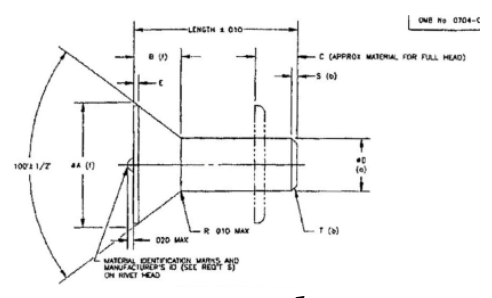

b

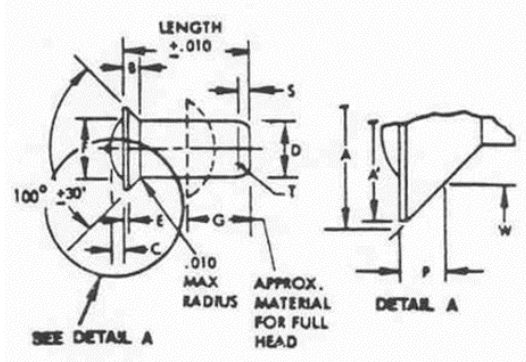

$c$

Fig. 3. US Standards - rivets: a) universal MS 20470 [15], b) $100^{\circ}$ countersunk MS 20426 [13], c) $100^{\circ}$ countersunk (reduced head) NAS 1097 [14].

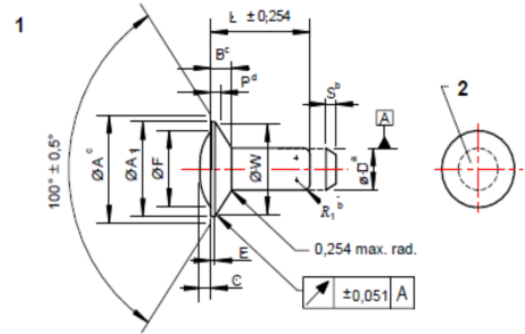

Fig. 4. European/Polish standards $-100^{\circ}$ reduced flush head rivet, close tolerance PN-EN 6069:2009 [20].

Tolerance of a shank diameter for investigated rivets differs with reference to different standards. In the case of the Polish industry standards it is within $0.1 \div 0.15 \mathrm{~mm}$, in the case of the Russian industry standards for rivets with a compensator (Fig. 2) it is within $0.04 \div 0.05 \mathrm{~mm}$, in the case of the western standards (Fig. 3), within $0.08 \div 0.1 \mathrm{~mm}$, and in the case of the European standard it is $0.06 \mathrm{~mm}$. Figure 5. presents a comparison of a nominal shank diameter and tolerance for rivets with a protruding head: the Polish round rivet and western universal rivet. It should be noted that the tolerance is reduced in the case of any analysed countersunk rivet (Fig. 6). In the case of rivets with a compensator (Fig. 2b and 2c) and European countersunk rivets (Fig. 4), the tolerance of the rivet shape - tolerance of a head and shank eccentricity, is specified.

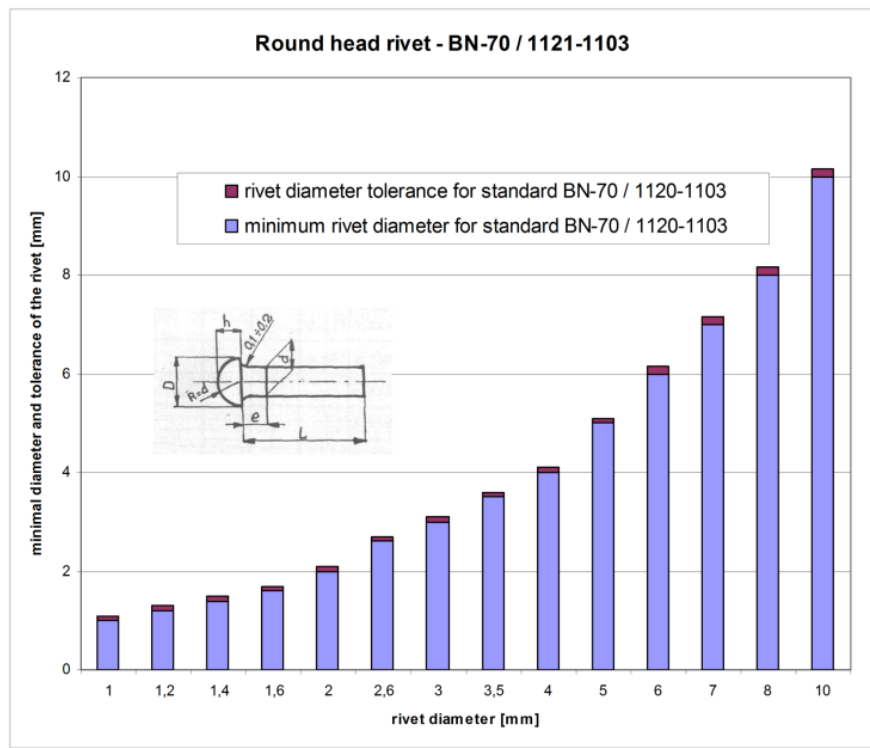




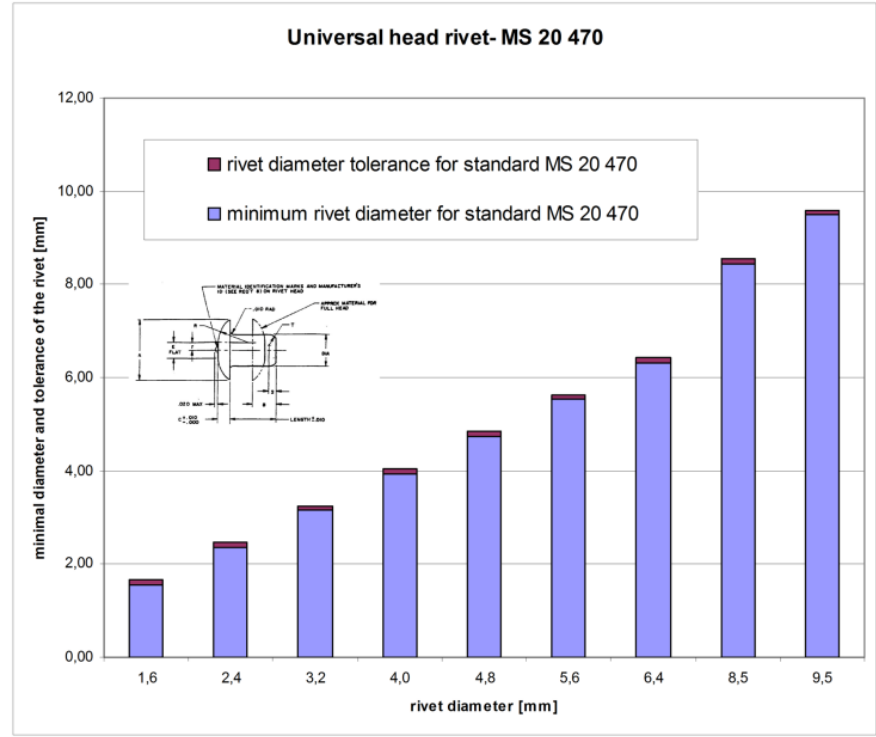

b)

Fig. 5. Comparison of minimal shank diameter and its tolerance for protruding rivets, a) round NB-70-1121-03, b) universal MS 20470

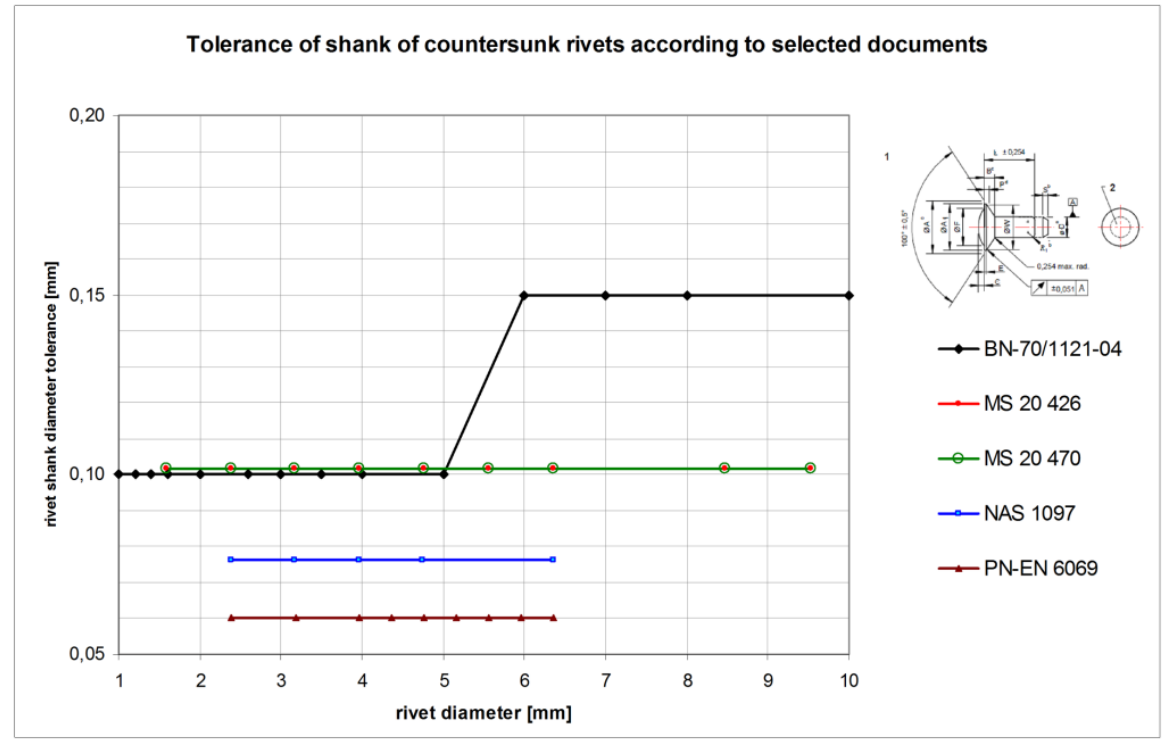

Fig. 6. Comparison of rivet shank diameter tolerance

The minimal and maximal rivet shank diameters with regard to the nominal diameters for countersunk rivets are presented in Fig. 7. It should be noted that the distances between curves of maximal and minimal diameters decrease as the rivet diameter increases.

The rivet shank end according to western standards can be finished with a $20^{\circ}$ chamfer or with a fillet (it refers also to PN-EN 6969:2009). Rivets manufactured to the Polish and Russian industry standards have flat shank ends. 


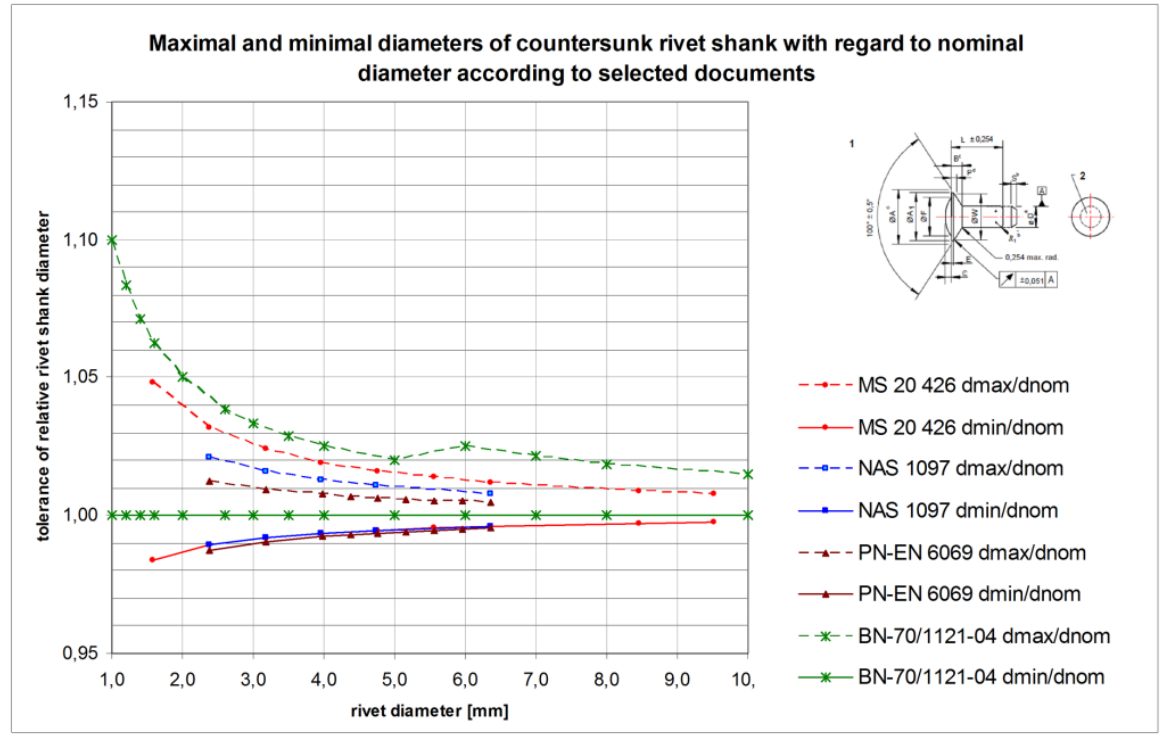

Fig. 7. Comparison of relative rivet shank diameter versus nominal diameter

\section{Rivet surface roughness}

None of the documents analyzed defined required surface roughness.

\section{Anti-corrosion protection}

Polish and Russian industry rivets standards suggest anodising (with sulphuric acid) for aluminium alloys. Lack of any protective layer is also allowed. The western standards also allow an alodine layer.

During squeezing anodized rivets, the anodic layer is crushed and hard anodic mini-pellets penetrate the area between the rivet and elements joined. This phenomenon fosters the acceleration of fatigue crack initiation, which means decreasing the fatigue life of a plane.

\section{RIVET HOLE PREPARATION}

The characteristics of the hole preparation as defined in the Polish industry standard BN-70/1120-03, Polish manufacturing instructions, for normal rivets Poland-1 and for rivets with a compensator Poland-2 as well as western manufacturing instructions West-1, West-2 and West-3 will be compared.

\section{Tolerances of the rivet hole diameter}

In the documents analysed, tolerances of a rivet hole diameter vary and often depend on a hole diameter. In the case of the Polish industry standard BN-70/1120-03 the tolerance is within $0.1 \div 0.2 \mathrm{~mm}$. The Polish manufacturing instruction Poland-1 slightly broadens the tolerance (compared to the industry standard) for solid rivets with a diameter of up to $6 \mathrm{~mm}$, while the instruction Poland-2 defines the tolerance as constant and equal to $0.12 \mathrm{~mm}$ for rivets with a compensator. Out of western manufacturing instructions, the West-3 instruction defines the largest tolerance - constant and equal to $0.15 \mathrm{~mm}$. The tolerance specified in the West- 1 is contained in a narrow range of $0.09 \div 0.12 \mathrm{~mm}$ (the smallest for large diameters). In the case of the West-2 instruction, the tolerance is constant and equal to $0.10 \mathrm{~mm}$ for manual drilling and 0.075 $\mathrm{mm}$ for automatic drilling. This is the smallest value specified in the analysed documents. 
All investigated instructions provide that a special tripod attachment be used to ensure the required perpendicularity of the hole axis and the element surface in the case of manual drilling. The western instructions specify the accuracy of the rivet axis and the element surface perpendicularity (Table 1.):

Table 1. Accuracy of the rivet hole axis perpendicularity in West-1 and West-3 instructions

\begin{tabular}{|c|c|}
\hline Instruction designation & $\begin{array}{l}\text { Required hole axis and element surface } \\
\text { perpendicularity }\end{array}$ \\
\hline West-3 & $90^{\circ} \pm 1^{\circ}$ \\
\hline West-1 & $\begin{array}{ll}\text { Automatic drilling: } & 90^{\circ} \pm 1^{\circ} \\
\text { Manual drilling: } & \\
& \text { for } \mathrm{d} \leq 4,8 \mathrm{~mm}: 90^{\circ} \pm 3^{\circ} \\
& \text { for } \mathrm{d}>4,8 \mathrm{~mm}: 90^{\circ} \pm 2^{\circ}\end{array}$ \\
\hline
\end{tabular}

The instruction Poland-1 specifies that: on curved surfaces with a radius of curvature less than $200 \mathrm{~mm}$ and in the places where it is difficult, it is allowed to drill without special tripod attachment.

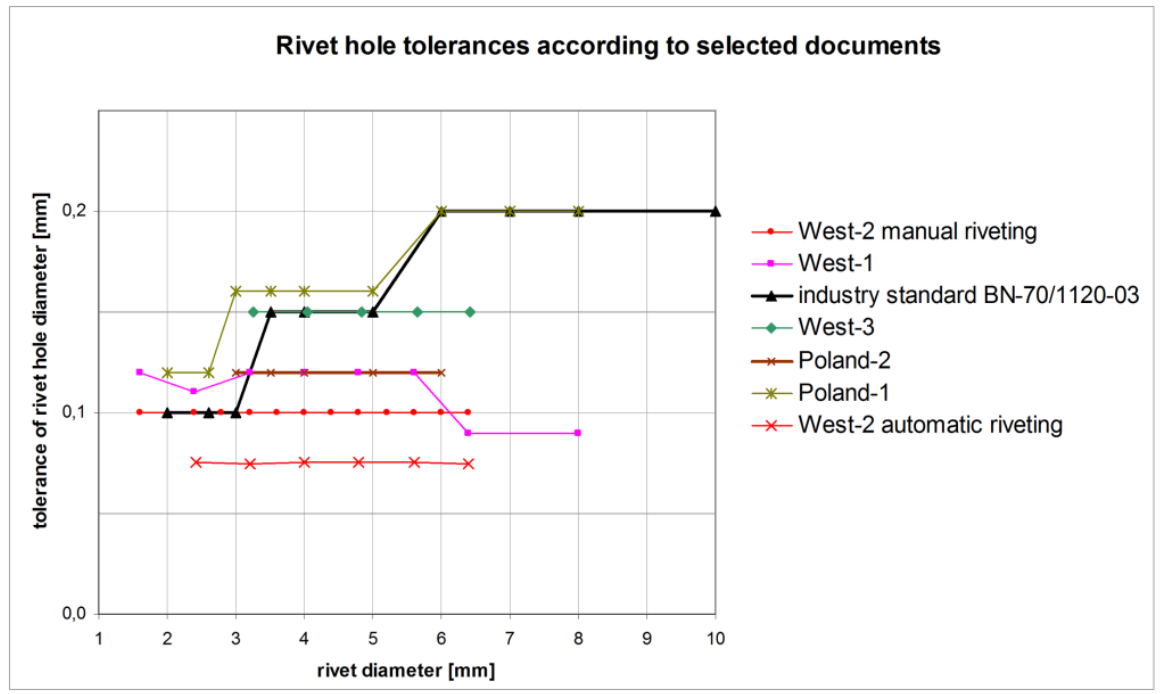

Fig. 8. Comparison of rivet hole diameter tolerances

The minimal and maximal rivet hole diameters with regard to the nominal diameters are presented in fig. 9. It should be noted that the distances between curves of $\mathrm{d}_{0 \mathrm{~min}} / \mathrm{d}_{\text {nom }}{ }^{1}$ (continuous lines) and $\mathrm{d}_{0 \mathrm{max}} / \mathrm{d}_{\text {nom }}$ (dash lines) decrease as the rivet diameter increases and the values of these rates are above 1 .

\footnotetext{
${ }^{1} \mathrm{~d}_{0 \min }, \mathrm{d}_{\text {nom }}, \mathrm{d}_{0 \max }-$ minimal, nominal, maximal rivet hole diameter
} 
Minimum and maximum diameter of rivet holes referred to nominal rivet diameter according to selected documents

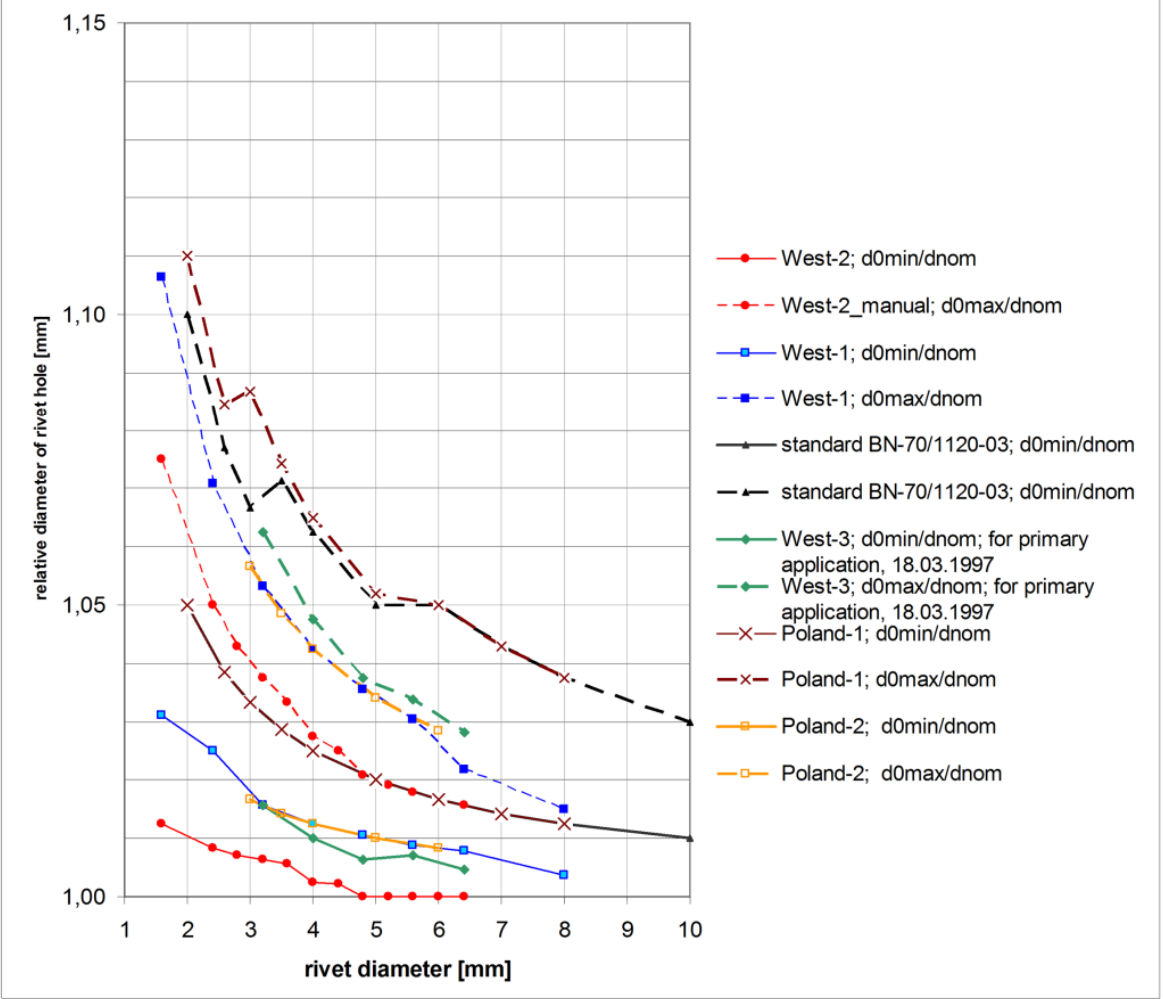

Fig. 9. Comparison of relative maximum and minimum diameters of rivet holes in relation to nominal diameters

\section{Surface roughness of the rivet hole}

According to the instruction Poland-1, the roughness after drilling holes should not be greater than Rz20 in the case of high-strength aluminium alloys (also in combination with steel or titanium alloys), Rz40 in the case of sheets made of D16 (2024) alloy only or in combination with high strength aluminium alloys, and Ra2.5 microns in the case of packages with a thickness greater than $3 \mathrm{~d}$ ( $\mathrm{d}$ - diameter of the rivet).

According to the instruction West-3, the required roughness of a hole should be $\mathrm{Ra} \leq 6,3 \mu \mathrm{m}$ (250 RH).

Instructions West-1 and West-2 suggest that the holes should be drilled in accordance with the instruction West-4. The West-4 instruction contains the following recommendations on the accuracy of the holes (Tab. 2): 
Table 2. Recommended drill types (West-4)

\begin{tabular}{|c|c|c|c|c|c|}
\hline \multirow{2}{*}{\multicolumn{2}{|c|}{ Drill type }} & \multicolumn{4}{|c|}{ Hole tolerance } \\
\hline & & \multirow{2}{*}{$\begin{array}{c}\mathrm{H} 8 \\
-\end{array}$} & \multirow{2}{*}{$\begin{array}{c}\mathrm{H} 10 \\
-\end{array}$} & \multirow{2}{*}{$\begin{array}{l}\mathrm{H} 11 \\
(\mathrm{X})\end{array}$} & \multirow{2}{*}{$\begin{array}{c}\mathrm{H} 12 / \mathrm{H} 1 \\
3 \\
\mathrm{X}\end{array}$} \\
\hline Twict drill (normol) & & & & & \\
\hline I wist drill (normal) & with predrill step & - & $(\mathrm{X})$ & $\mathrm{X}$ & $\mathrm{X}$ \\
\hline \multirow{2}{*}{ Twist drill with 2 lands } & $\mathrm{d} \leq 6,4 \mathrm{~mm}$ & - & $(\mathrm{X})$ & $\mathrm{X}$ & $\mathrm{X}$ \\
\hline & with predrill step & - & $\mathrm{X}$ & $\mathrm{X}$ & $\mathrm{X}$ \\
\hline $\begin{array}{l}\text { Combination drill and countersink } \\
\text { with controlled feed }\end{array}$ & & - & $\mathrm{X}$ & $\mathrm{X}$ & $\mathrm{X}$ \\
\hline
\end{tabular}

- $\quad$ not suitable

(X) conditionally suitable

X suitable

\section{Rivet hole countersink}

All analysed instructions provide that special tools be used to machine countersinking for a rivet. The axis of a countersink should coincide with the axis of a hole. To meet this requirement, a pilot countersink is used or a hole and a countersink are performed in one operation with the use of combined drill and countersink - the latter method being preferred by the West- 4 instruction.

The Poland-1 instruction provides that the maximal depth of a countersink be about $0.01 \mathrm{~mm}$ less than the minimum height of a countersunk rivet head, and the minimal depth of a countersink be determined according to an aircraft's technical specification taking into consideration data in Table 3:

Table 3. Countersink depth (Poland-1 instruction)

\begin{tabular}{|c|c|c|}
\hline \multicolumn{2}{|c|}{$\begin{array}{c}\text { Maximal protrusion of the rivet head above the sheet } \\
\text { surface [mm] }\end{array}$} & \multirow{2}{*}{ Comments } \\
\hline after riveting & before riveting & Countersinking on bench drill \\
\hline 0,05 & 0,08 & - \\
\hline 0,15 & 0,17 & - \\
\hline 0,20 & 0,22 & \\
\hline
\end{tabular}

The Poland-2 instruction provides that in the case of a rivet with a compensator, between a countersink and an outer sheet surface there should be a cylindrical part of a hole (counterbore) with a specified depth. The surface roughness of this part should not be greater than Rz20.

The Poland-1 instruction states that the countersink angle should correspond to the rivet head angle. The western instructions specify the accuracy of the countersink angle (Table 4.):

Table 4. Countersink angle

\begin{tabular}{|c|c|}
\hline Instruction designation & Required accuracy of the countersink angle \\
\hline West-3 & $100^{\circ} \pm 30^{\prime} ; 120^{\circ} \pm 0,5^{\circ}$ \\
\hline West-4 & $100^{\circ} \pm 0,5^{\circ} ; 130^{\circ} \pm 0,5^{\circ}$ \\
\hline Poland-1 & $90^{\circ} \pm 30^{\prime} ; 120^{\circ} \pm 0,5^{\circ}$ \\
\hline
\end{tabular}


The West- 1 instruction recommends that a rivet head before riveting protrude no more than 0.1 $\mathrm{mm}$ above the sheet surface. The West-3 instruction provides that a diameter of the countersink (Fig. 10) should be at most equal to the minimal rivet head diameter and not smaller than the rivet head diameter minus $0.15 \mathrm{~mm}$.

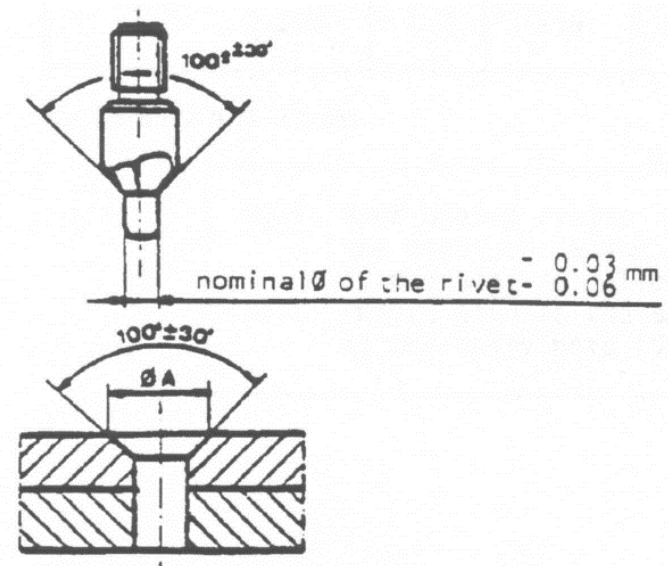

Fig. $10.100^{\circ}$ countersink for the rivet according to West-3 instruction

According to the West-4 instruction, maximal allowed eccentrity of a countersink and a hole is equal to $0.05 \mathrm{~mm}$. In order to ensure good contact between a countersunk head and a countersink, the transition area between a countersink and a cylindrical part of the hole needs to be chamfered as shown in Fig. 11.

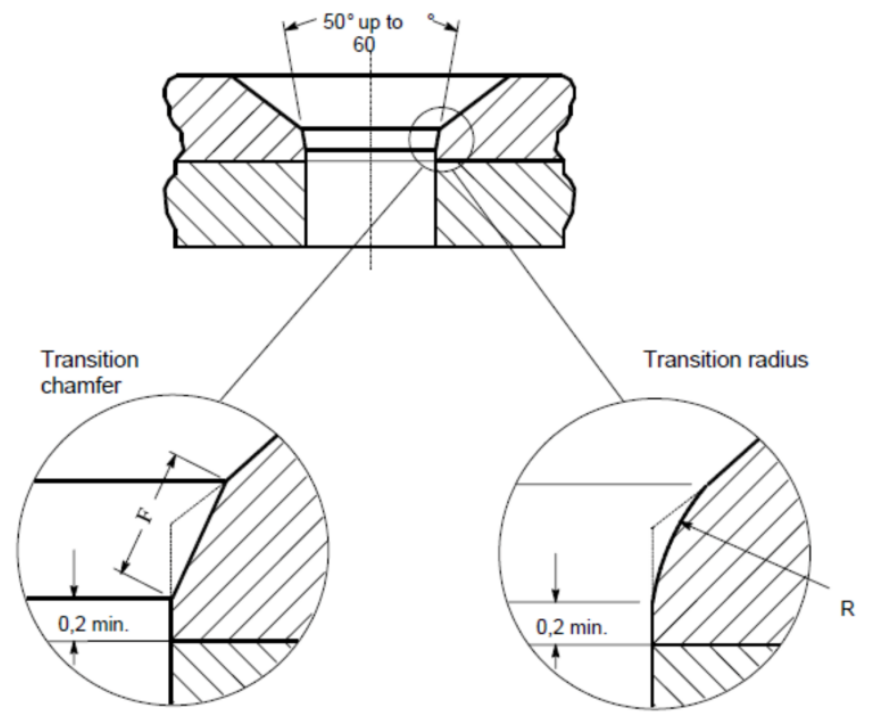

Fig. 11. Chamfer on the edge between countersunk and cylindrical part of hole

All instructions recommended that a cylindrical portion of a hole should be not less than 0.2 mm, Fig. 11.

\section{Clearance between the rivet shank and the hole}

The clearance between a rivet shank and a hole depends on tolerances of a rivet and a hole. The maximum clearance occurs in the case of a maximal allowable hole diameter and a rivet with a minimal diameter. The minimal clearance means that a rivet with a maximal allowable diameter 
is inserted into a hole with a minimal diameter. Figures 12 to 29 present tolerance ranges for selected pairs: a rivet and a hole drilled according to a particular instruction.

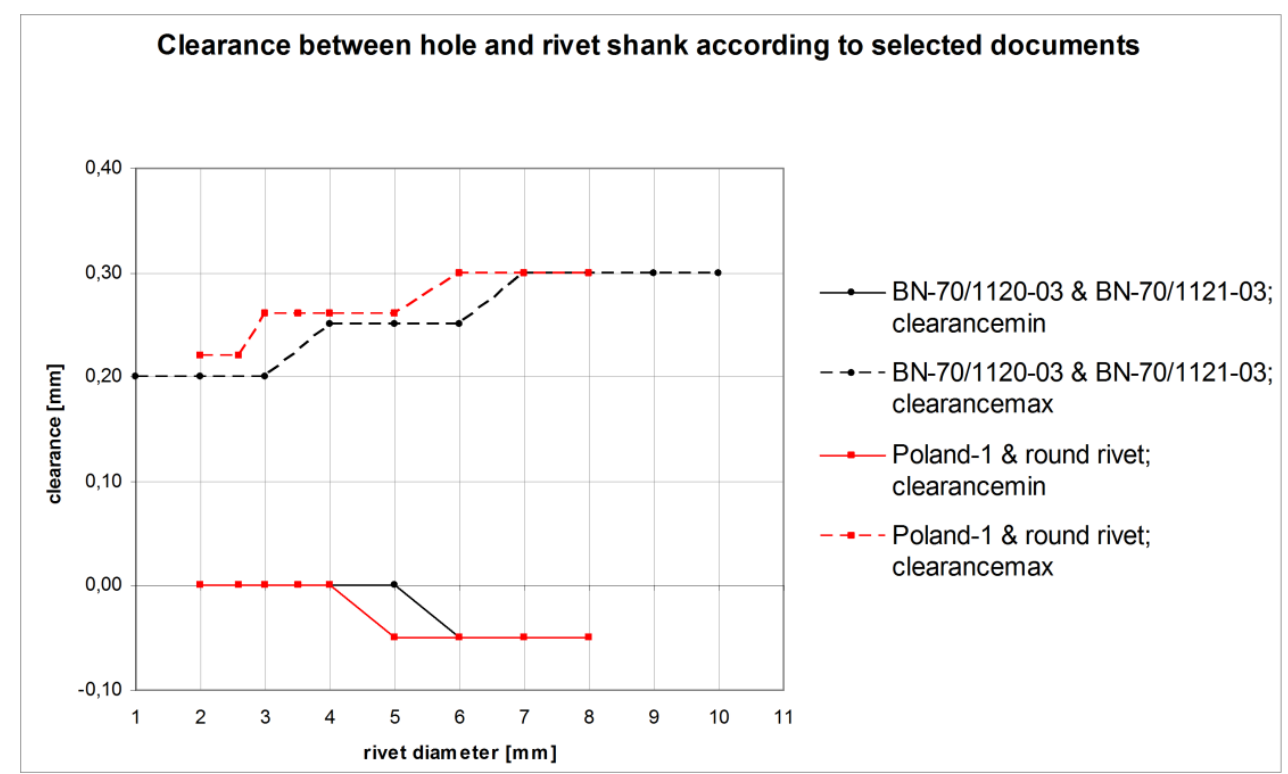

Fig. 12. Comparison of clearance between the shank of a rounded rivet BN 70/1121-03, and holes made according to Polish standard BN 70/1120-03 and according to riveting instructions Poland-1

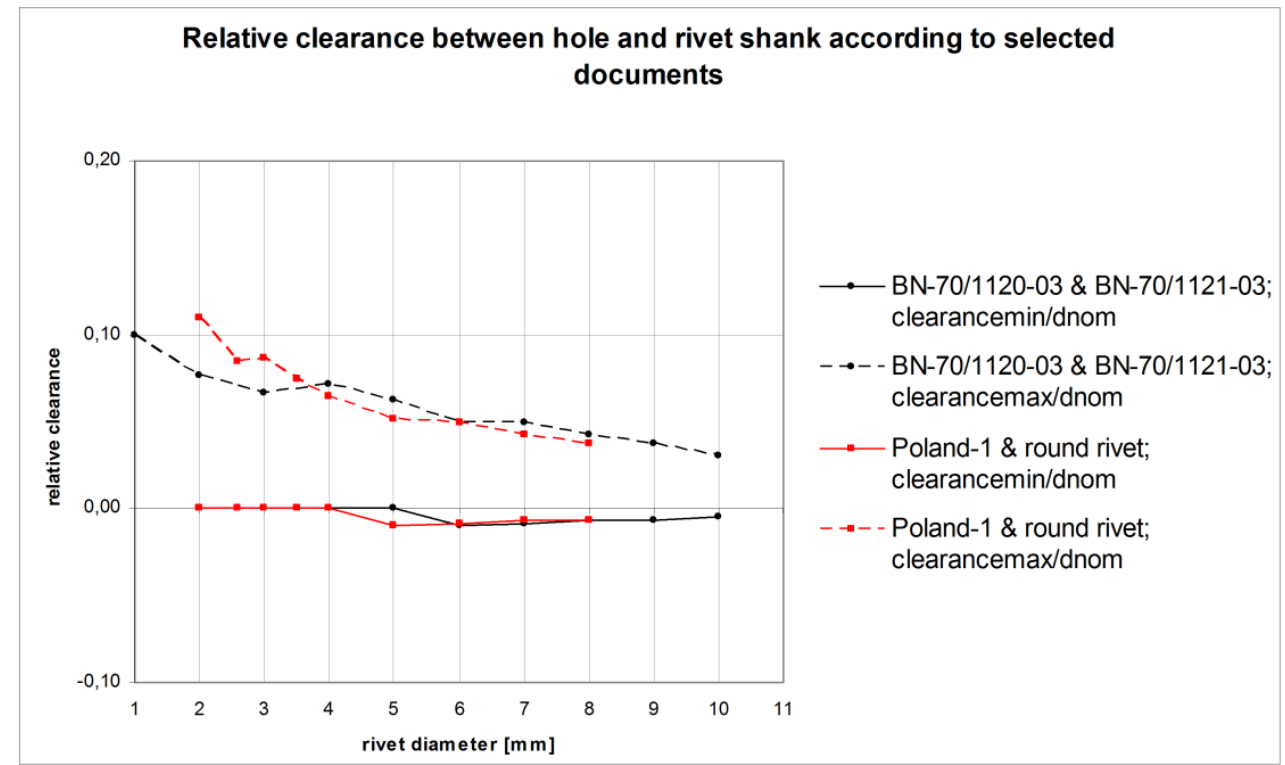

Fig. 13. Comparison of relative clearance (with regard to nominal rivet diameter) between the shank of a rounded rivet $B N$ 70/1121-1103, and holes made according to Polish standard BN 70/1120-03 and according to riveting instructions Poland-1 


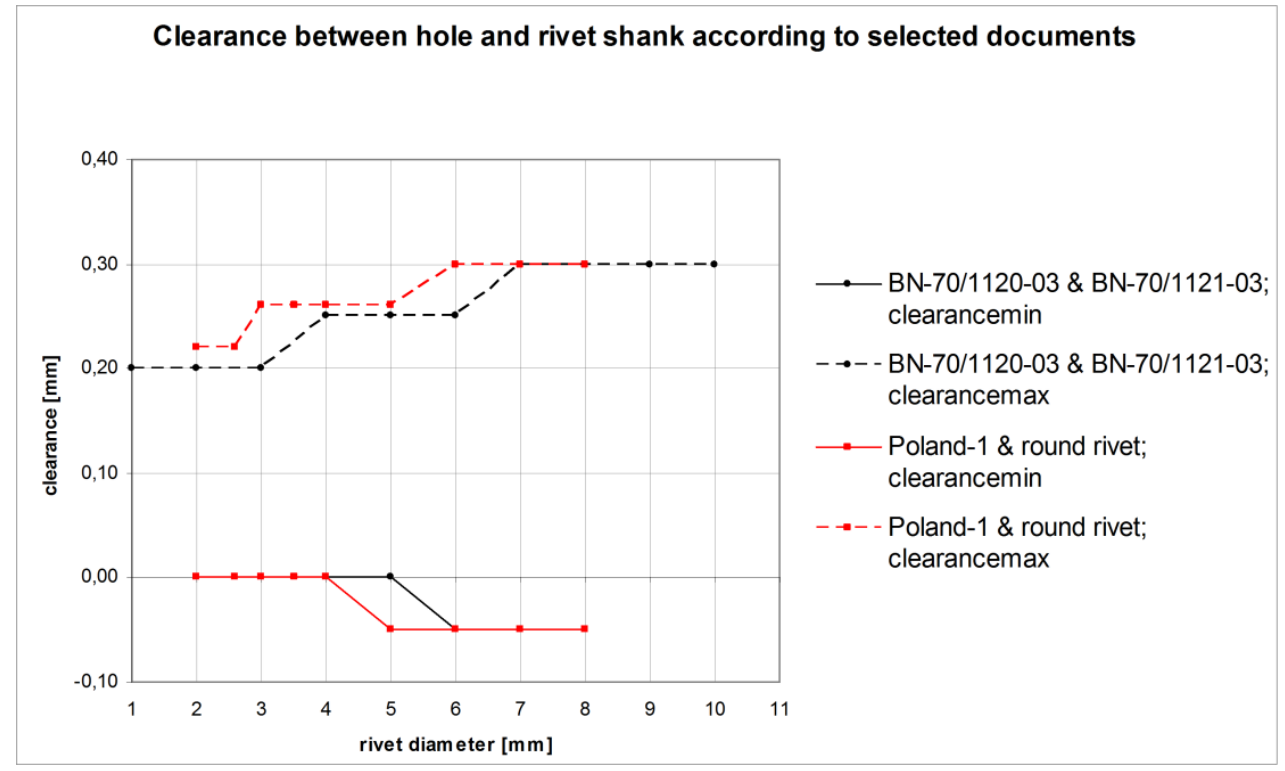

Fig. 14. Comparison of clearance between the hole and rivet shank for pairs:

- hole according to Poland-1 instruction - shank of a rounded rivet according to BN-70/1121-03 standard,

- hole according to Poland-2 instruction - shank of a brazier rivet with a compensator (OST 1 34040-79).

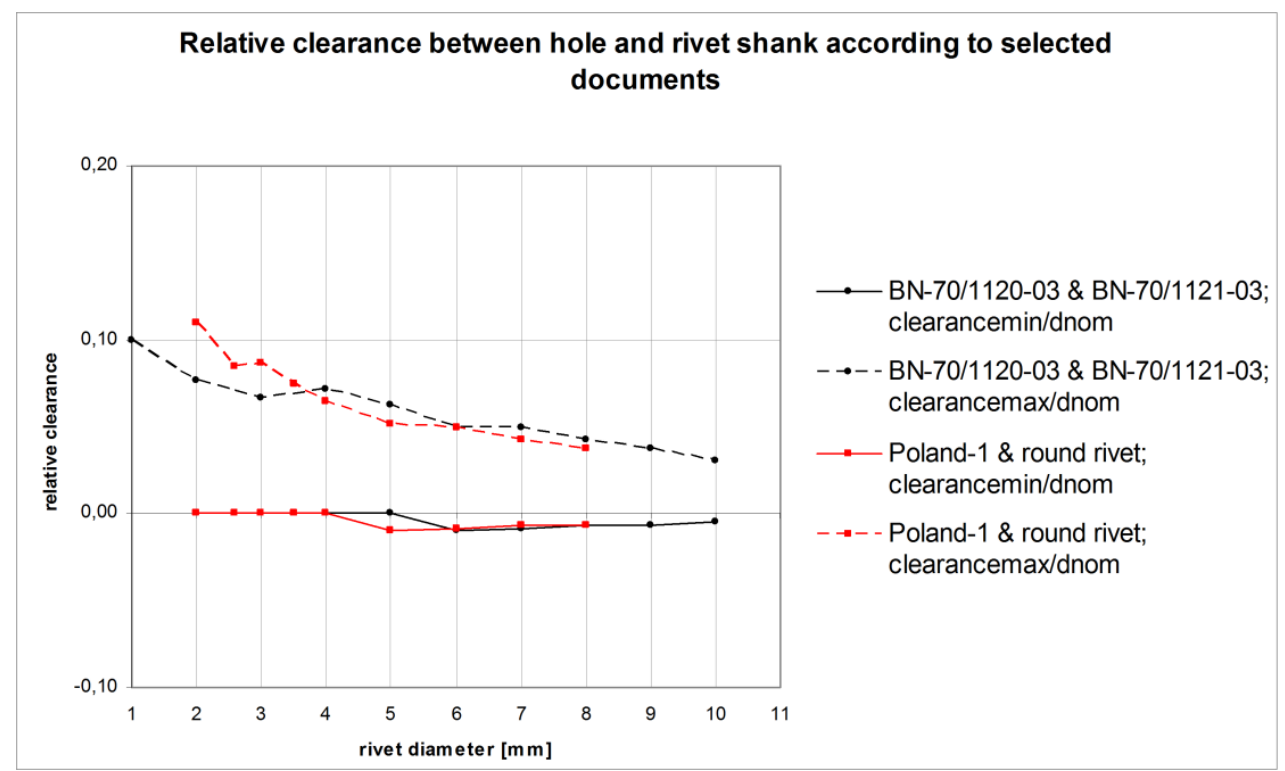

Fig. 15. Comparison of relative clearance (with regard to nominal rivet diameter) between the hole and rivet shank for pairs:

- hole according to Poland-1 instruction - shank of a rounded rivet according to BN-70/1121-03 standard,

- hole according to Poland-2 instruction - shank of the brazier rivet with a compensator (OST 1 34040-79). 
Clearance between hole and rivet shank according to selected documents

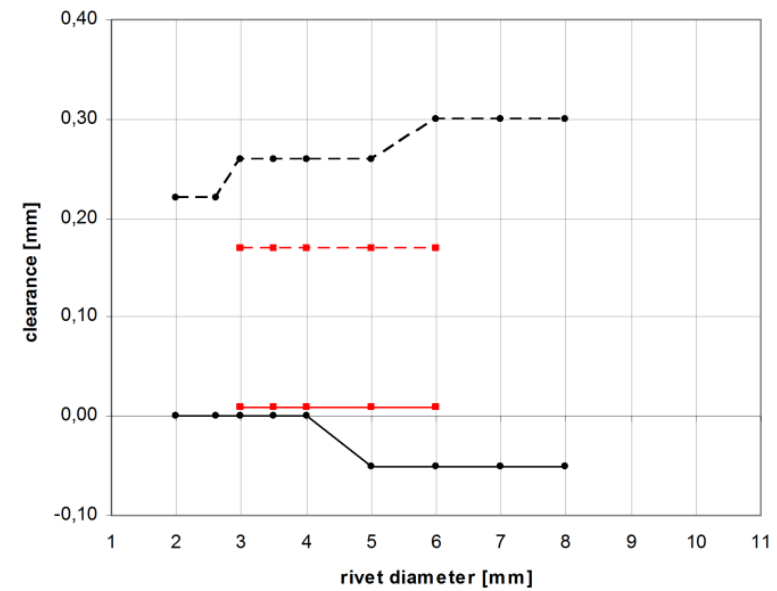

- Poland-1 \& round rivet; clearancemin

- $\rightarrow$ - - Poland-1 \& round rivet; clearancemax

- Poland-2 \& rivet with a compensator; clearancemin

- $\rightarrow-$ - Poland-2 \& rivet with a compensator; clearancemax

Fig. 16. Comparison of clearance between the hole and rivet shank for pairs:

- hole according to Poland-2 instruction - shank of the brazier rivet with compensator (OST 1 34040-79),

- hole according to West-1 instruction - shank of the universal rivet MS 20470.

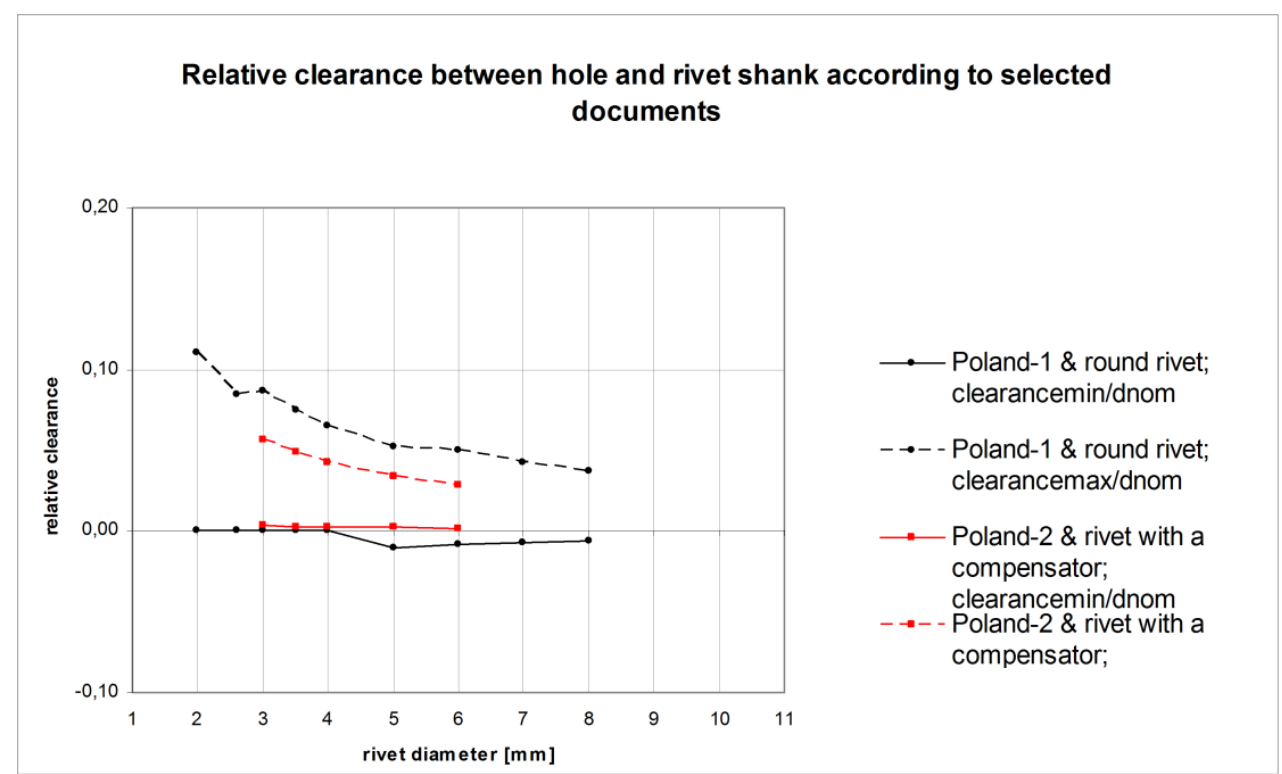

Fig. 17. Comparison of relative clearance (with regard to nominal rivet diameter) between the hole and rivet shank for pairs:

- hole according to Poland-2 instruction - shank of the brazier rivet with compensator (OST 1 34040-79),

- hole according to West-1 instruction - shank of the universal rivet MS 20470. 


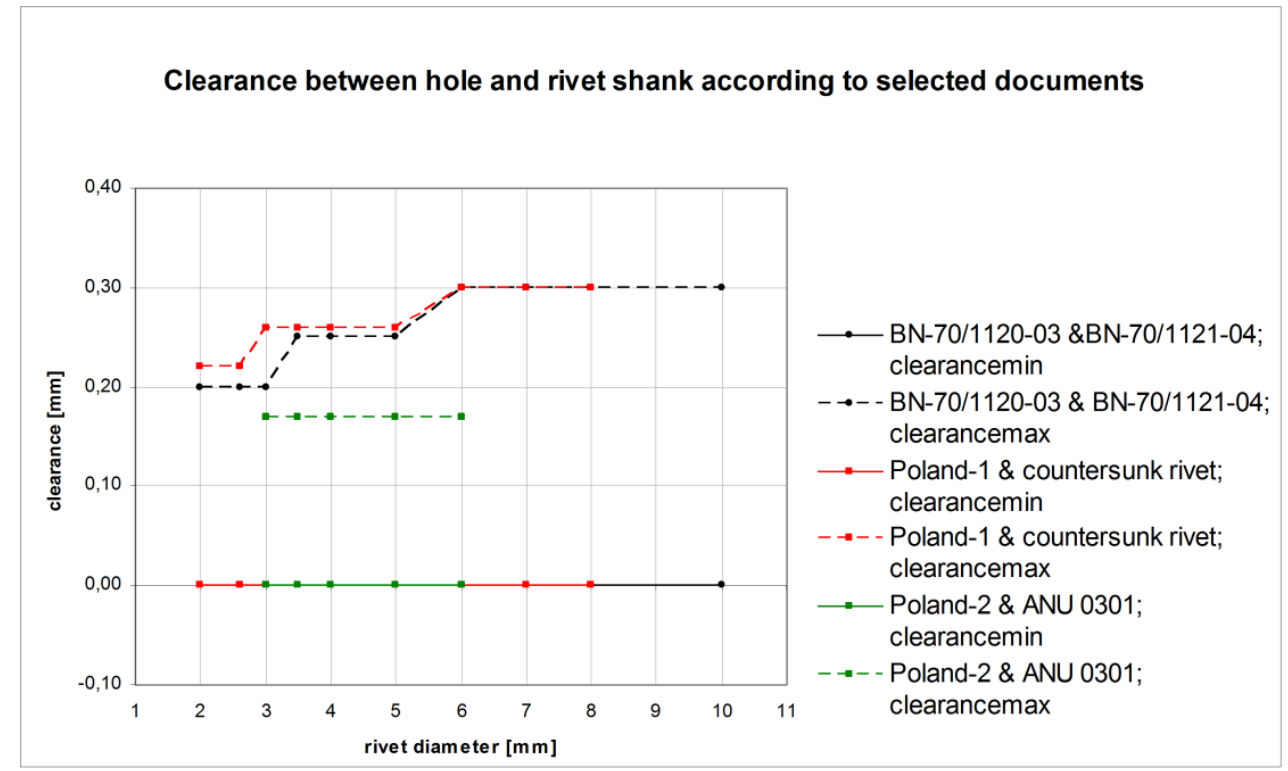

Fig. 18. Comparison of clearance between the hole and rivet shank for pairs:

- hole according to BN-70/1120-03 standard- shank of a countersunk rivet BN-70/1121-04, - hole according to Poland-1 instruction - shank of a countersunk rivet BN-70/1121-04, - hole according to Poland-2 instruction - shank of a countersunk rivet with the compensator ANU 0301.

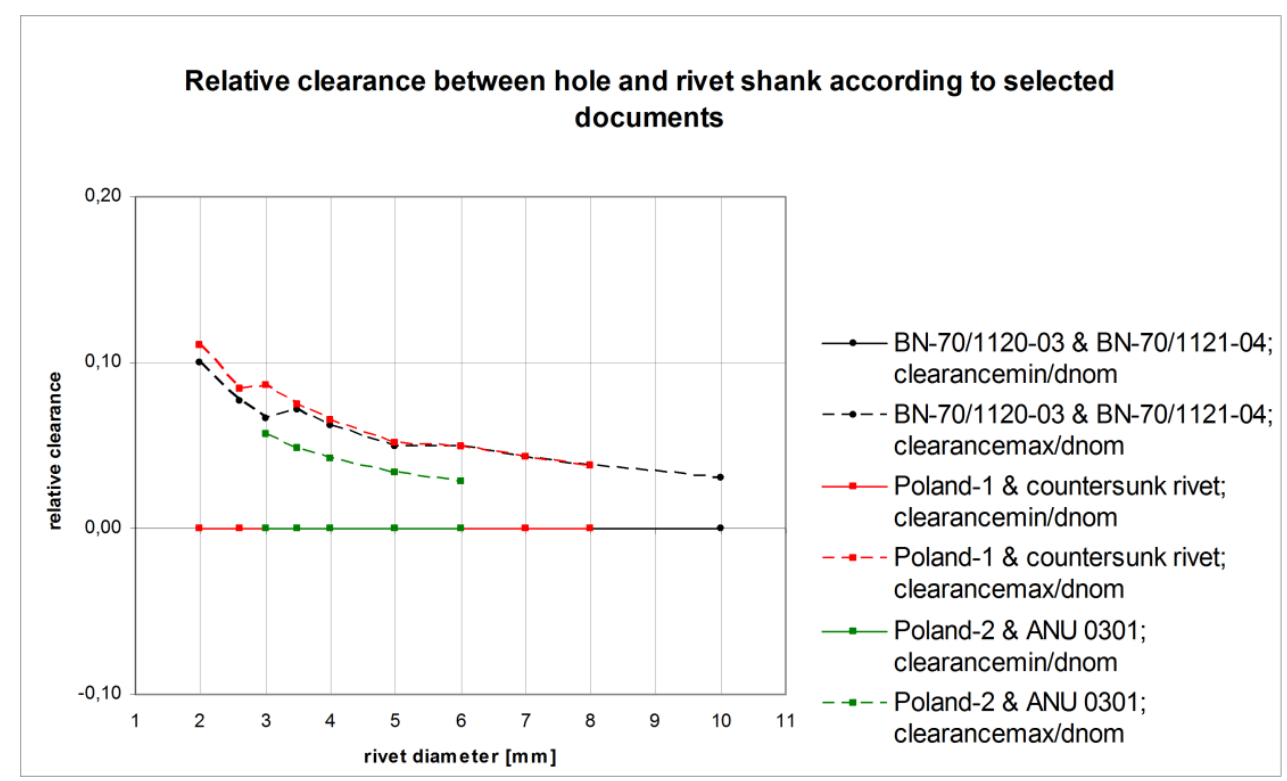

Fig. 19. Comparison of relative clearance (with regard to nominal rivet diameter) between the hole and rivet shank for pairs:

- hole according to BN-70/1120-03 standard- shank of a countersunk rivet BN-70/1121-04,

- hole according to Poland-1 instruction - shank of a countersunk rivet BN-70/1121-04,

- hole according to Poland-2 instruction - shank of a countersunk rivet with the compensator ANU 0301. 


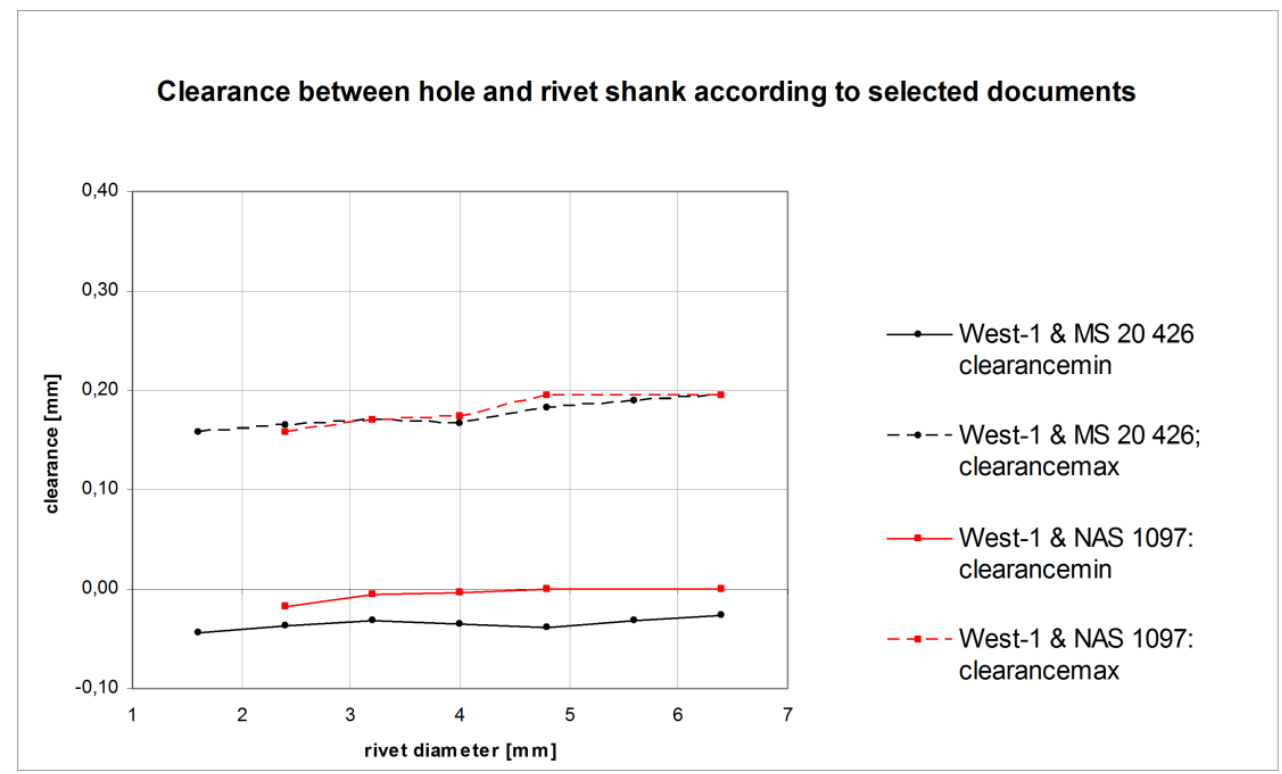

Fig. 20. Comparison of clearance between the hole and rivet shank for pairs:

- hole according to West-1 instruction-shank of a $100^{\circ}$ countersunk rivet MS 20426 , - hole according to West-1 instruction-shank of a 100' countersunk rivet NAS 1097.

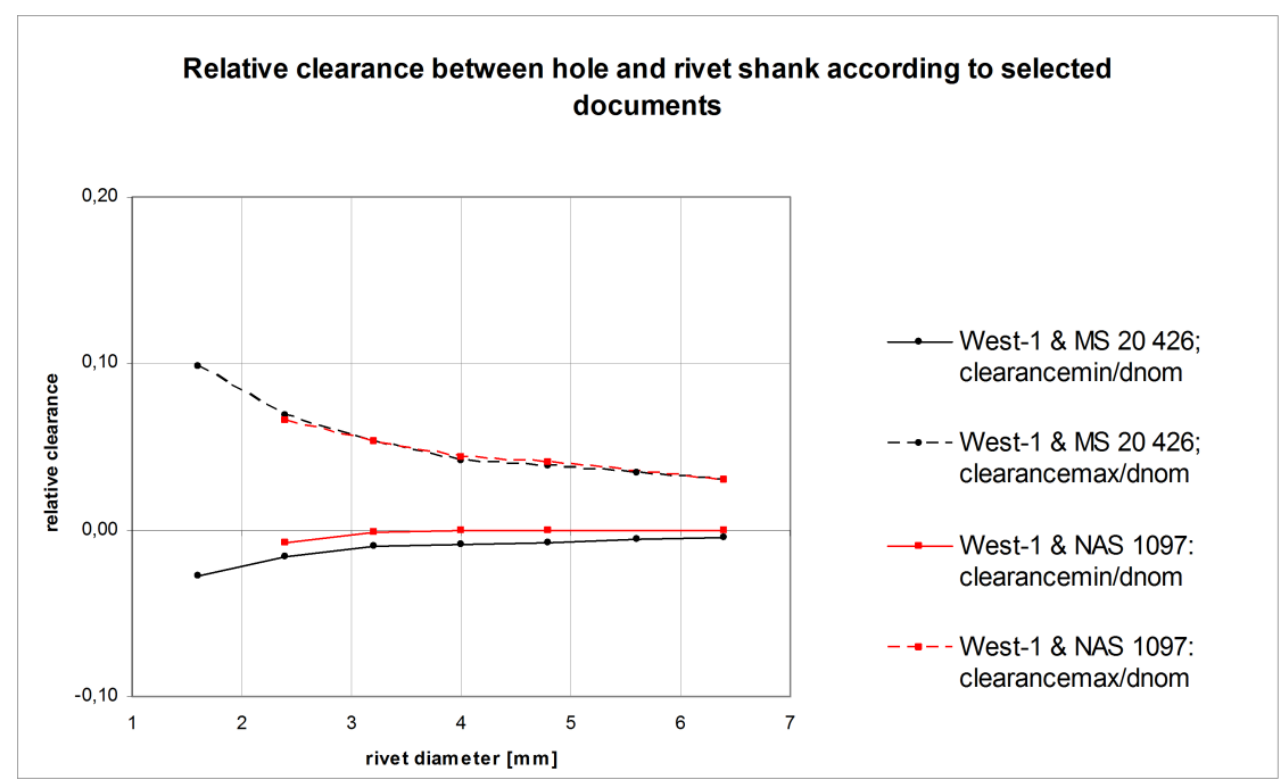

Fig. 21. Comparison of relative clearance (with regard to nominal rivet diameter) between the hole and rivet shank for pairs:

- hole according to West-1 instruction- shank of a $100^{\circ}$ countersunk rivet MS 20426 , - hole according to West-1 instruction-shank of a 100' countersunk rivet NAS 1097. 


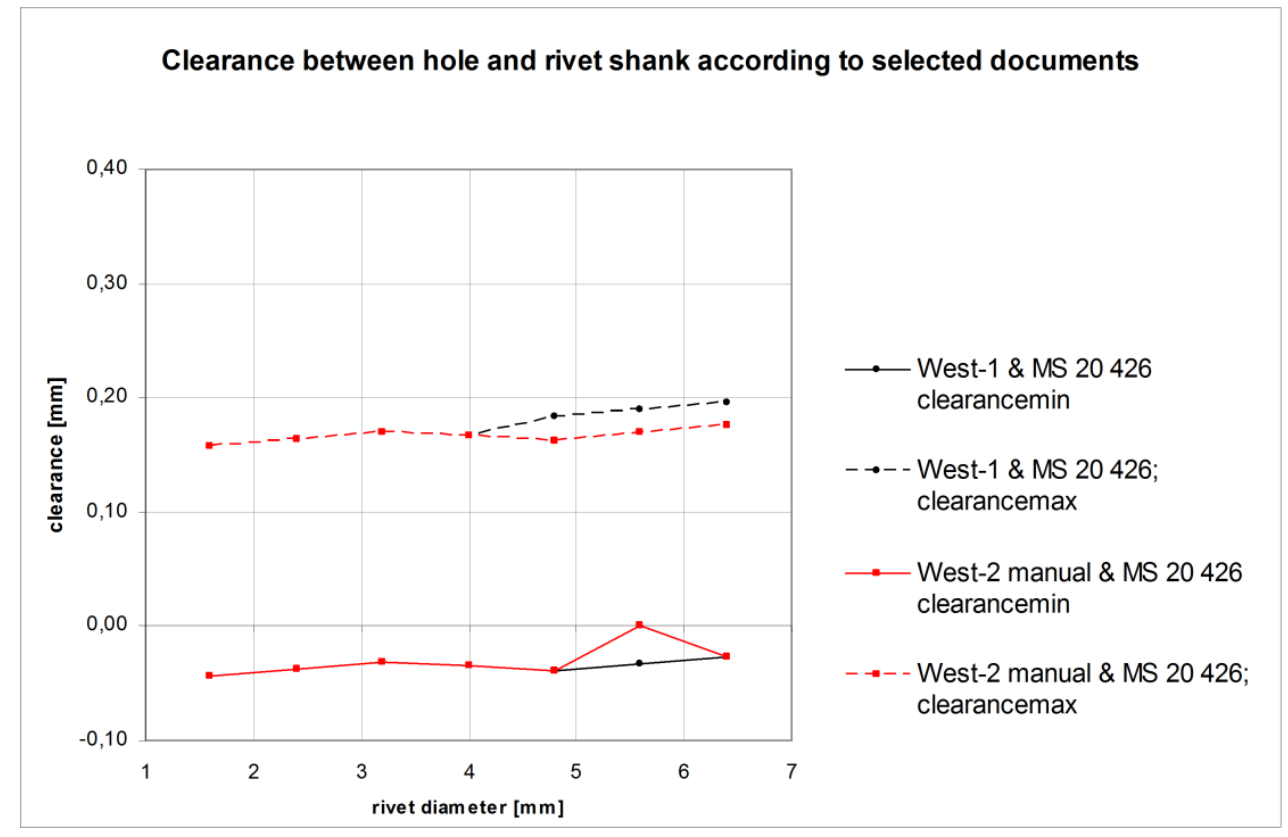

Fig. 22. Comparison of clearance between the hole and rivet shank for pairs:

- hole according to West-1 instruction- shank of a $100^{\circ}$ countersunk rivet MS 20426 , - hole according to West-2 instruction- shank of a 100' countersunk rivet MS 20426.

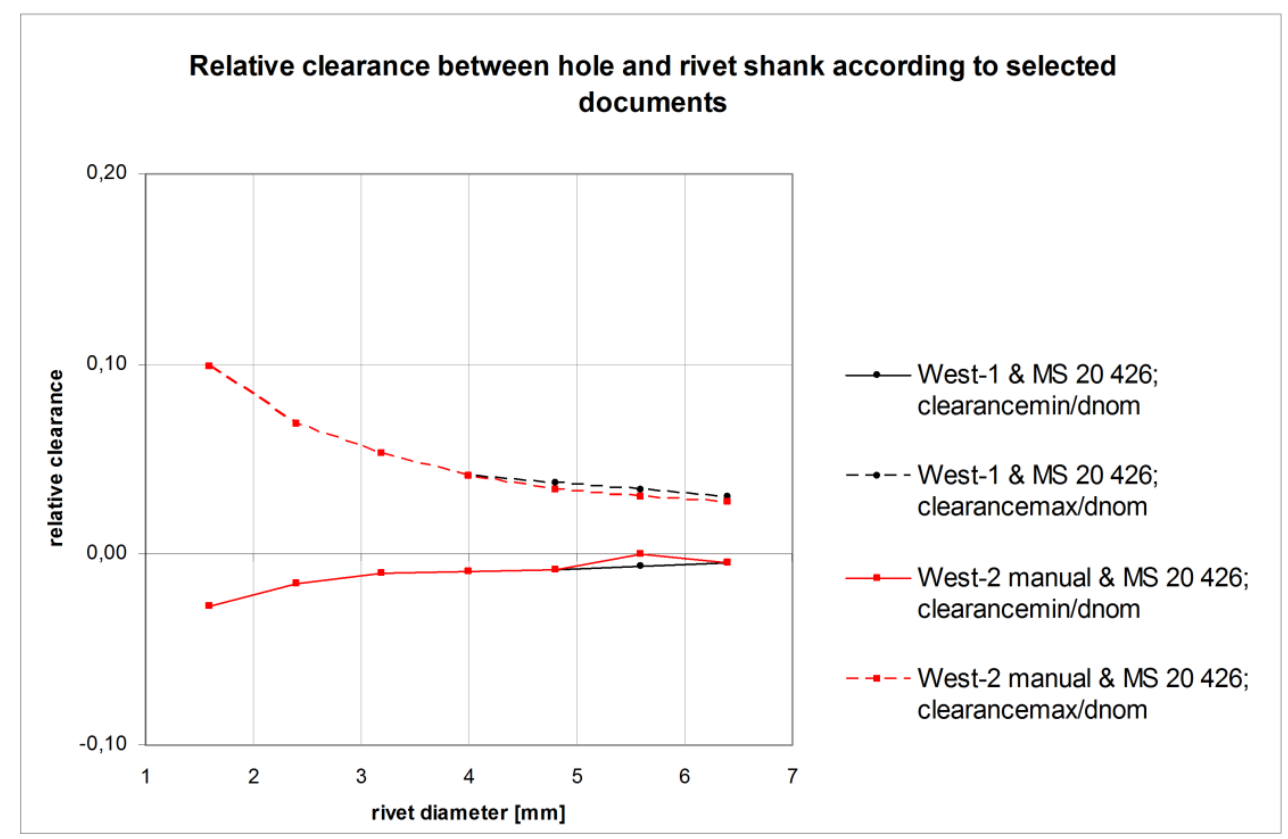

Fig. 23. Comparison of relative clearance between the hole and rivet shank for pairs:

- hole according to West-1 instruction- shank of a $100^{\circ}$ countersunk rivet MS 20426 , - hole according to West-2 instruction-shank of a $100^{\circ}$ countersunk rivet MS 2042. 


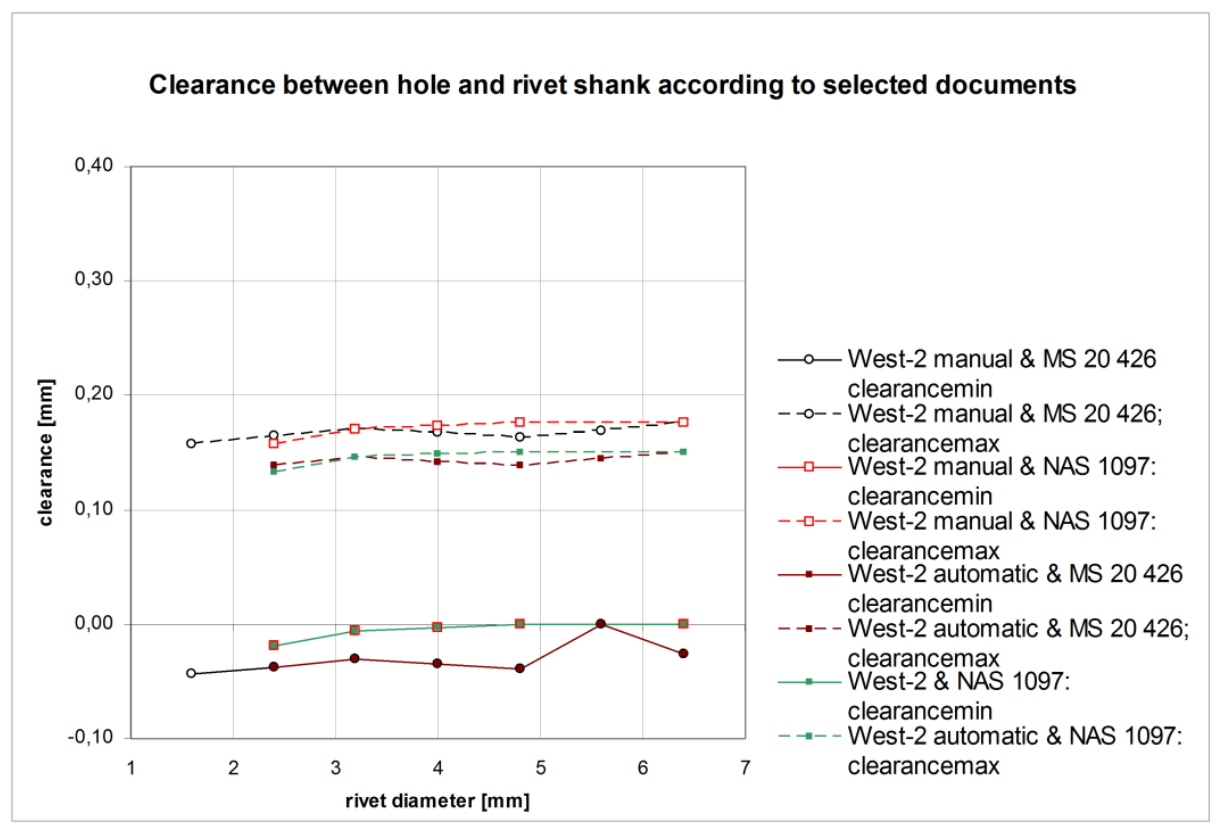

Fig. 24. Comparison of clearance between the hole and rivet shank for four pairs:

- hole according to West-1 instruction, manual riveting - shank of a $100^{\circ}$ countersunk rivet MS 20 426, - hole according to West-2 instruction, manual riveting - shank of a $100^{\circ}$ countersunk rivet NAS 1097, - hole according to West-1 instruction, automatic riveting - shank of a $100^{\circ}$ countersunk rivet MS 20 426, - hole according to West-2 instruction, automatic riveting - shank of a $100^{\circ}$ countersunk rivet NAS 1097.

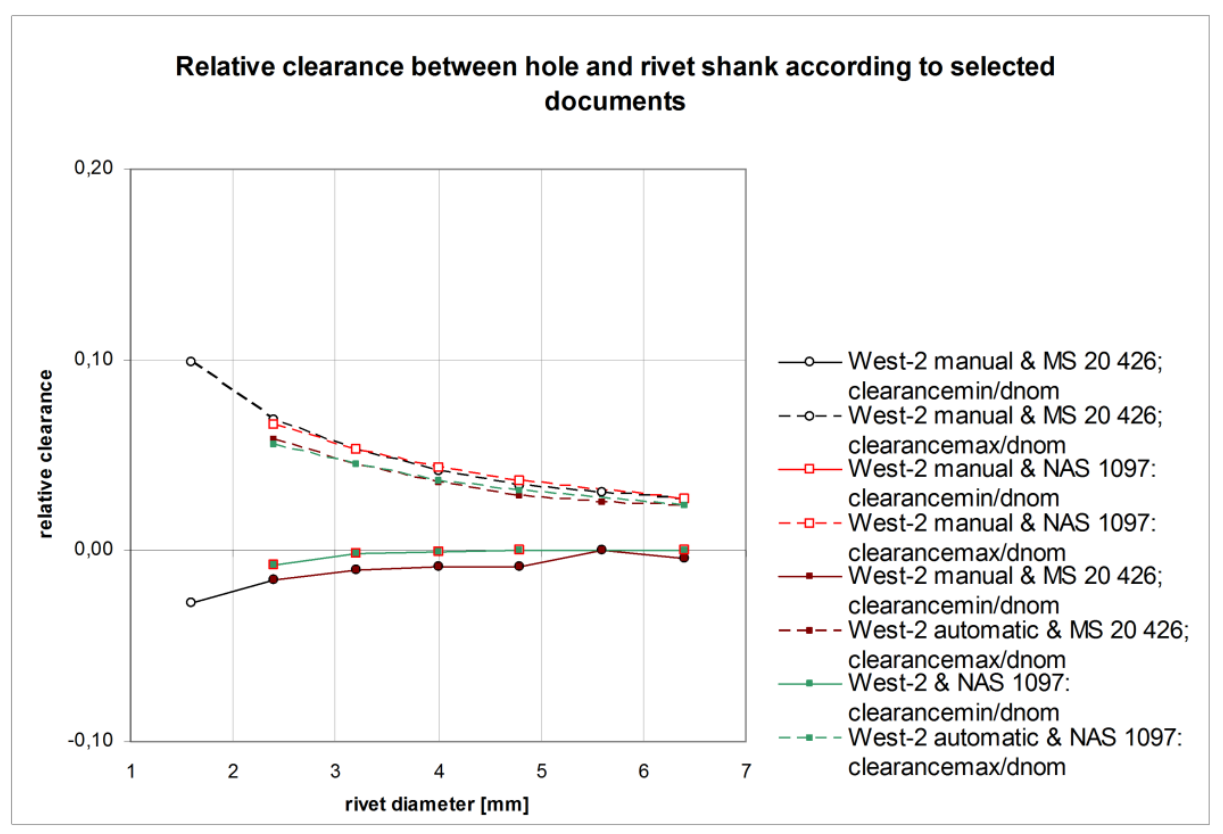

Fig. 25. Comparison of relative clearance (with regard to nominal rivet diameter) between the hole and rivet shank for four pairs:

- hole according to West-1 instruction, manual riveting - shank of a $100^{\circ}$ countersunk rivet MS 20 426, - hole according to West-2 instruction, manual riveting - shank of a $100^{\circ}$ countersunk rivet NAS 1097, - hole according to West-1 instruction, automatic riveting - shank of a 100 ${ }^{\circ}$ countersunk rivet MS 20 426, - hole according to West-2 instruction, automatic riveting - shank of a $100^{\circ}$ countersunk rivet NAS 1097. 


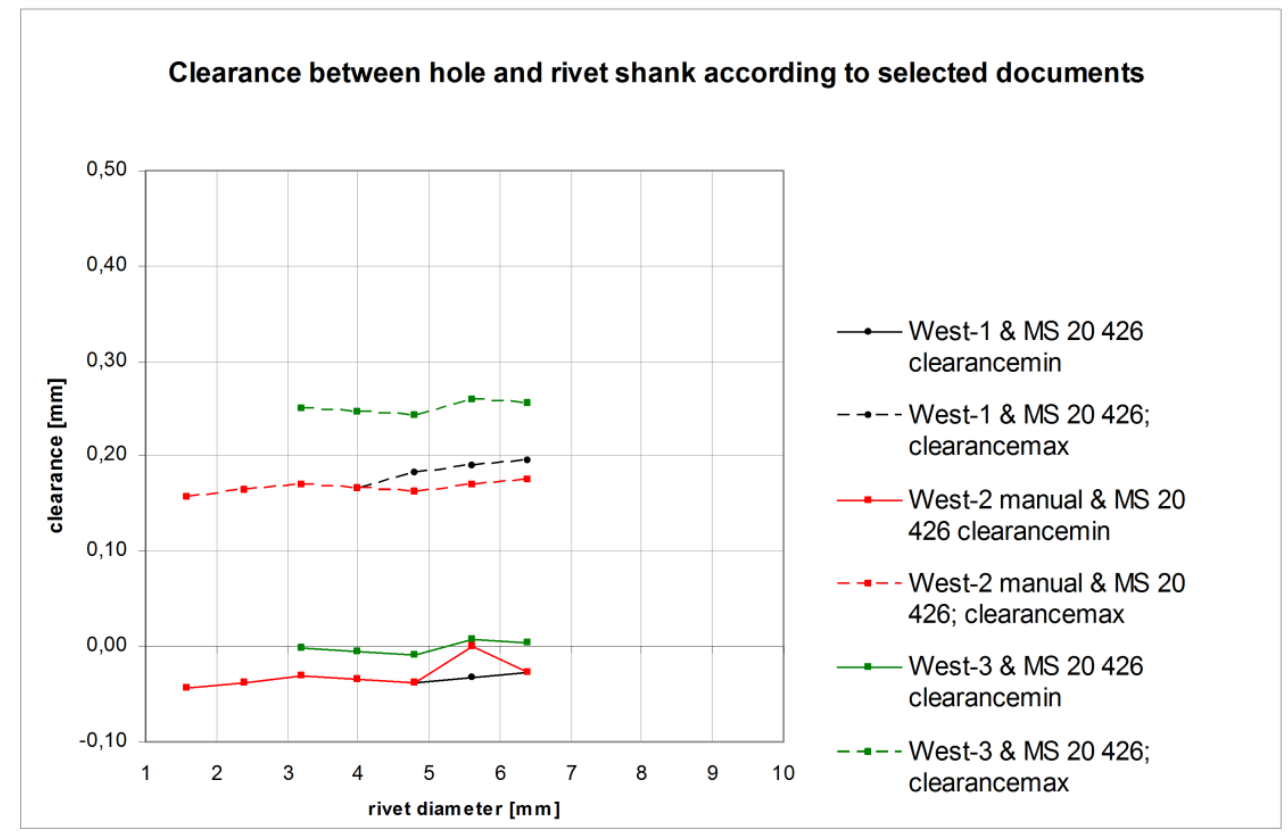

Fig. 26. Comparison of clearance between the hole and rivet shank for three pairs:

- hole according to West-1 instruction - shank of a $100^{\circ}$ countersunk rivet MS 20426 , - hole according to West-2 instruction, manual riveting - shank of a $100^{\circ}$ countersunk rivet MS 20 426,

- hole according to West-3 instruction - shank of a $100^{\circ}$ countersunk rivet MS 20426.

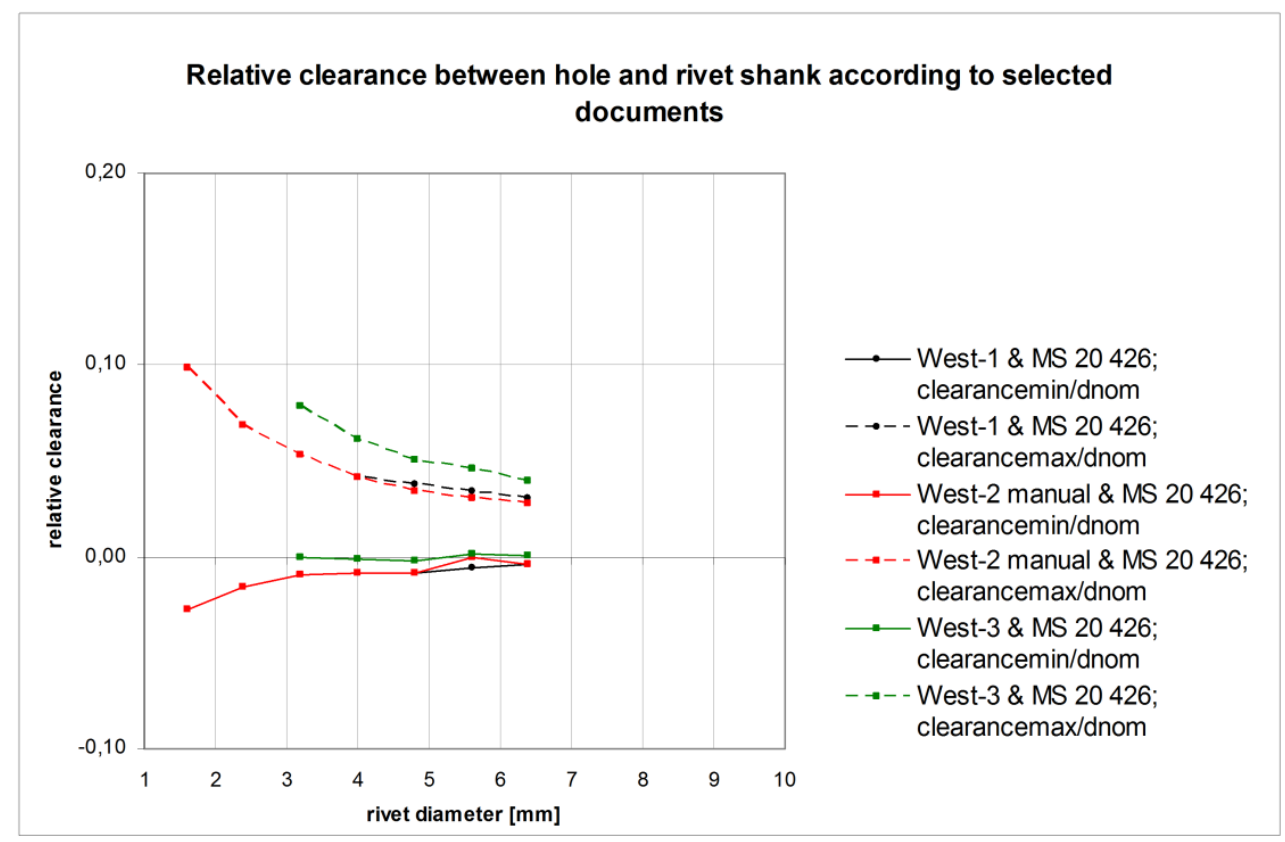

Fig. 27. Comparison of relative clearance (with regard to nominal rivet diameter) between the hole and rivet shank for three pairs:

- hole according to West-1 instruction - shank of a 100' countersunk rivet MS 20426 , - hole according to West-2 instruction, manual riveting - shank of a $100^{\circ}$ countersunk rivet MS 20 426,

- hole according to West-3 instruction - shank of a $100^{\circ}$ countersunk rivet MS 20426. 


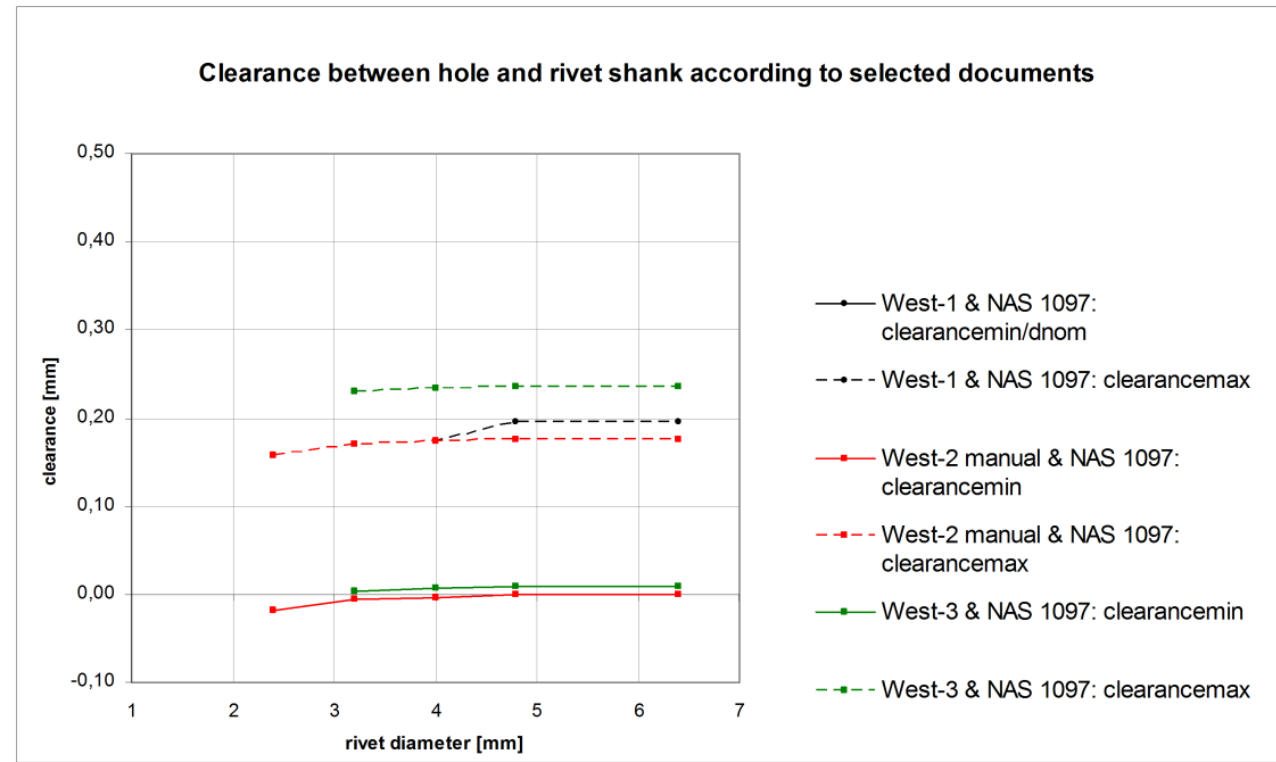

Fig. 28. Comparison of clearance between the hole and rivet shank for three pairs:

- hole according to West-1 instruction - shank of a $100^{\circ}$ countersunk rivet NAS 1097,

- hole according to West-2 instruction, manual riveting - shank of a $100^{\circ}$ countersunk rivet, NAS 1097

- hole according to West-3 instruction - shank of a 100' countersunk rivet NAS 1097.

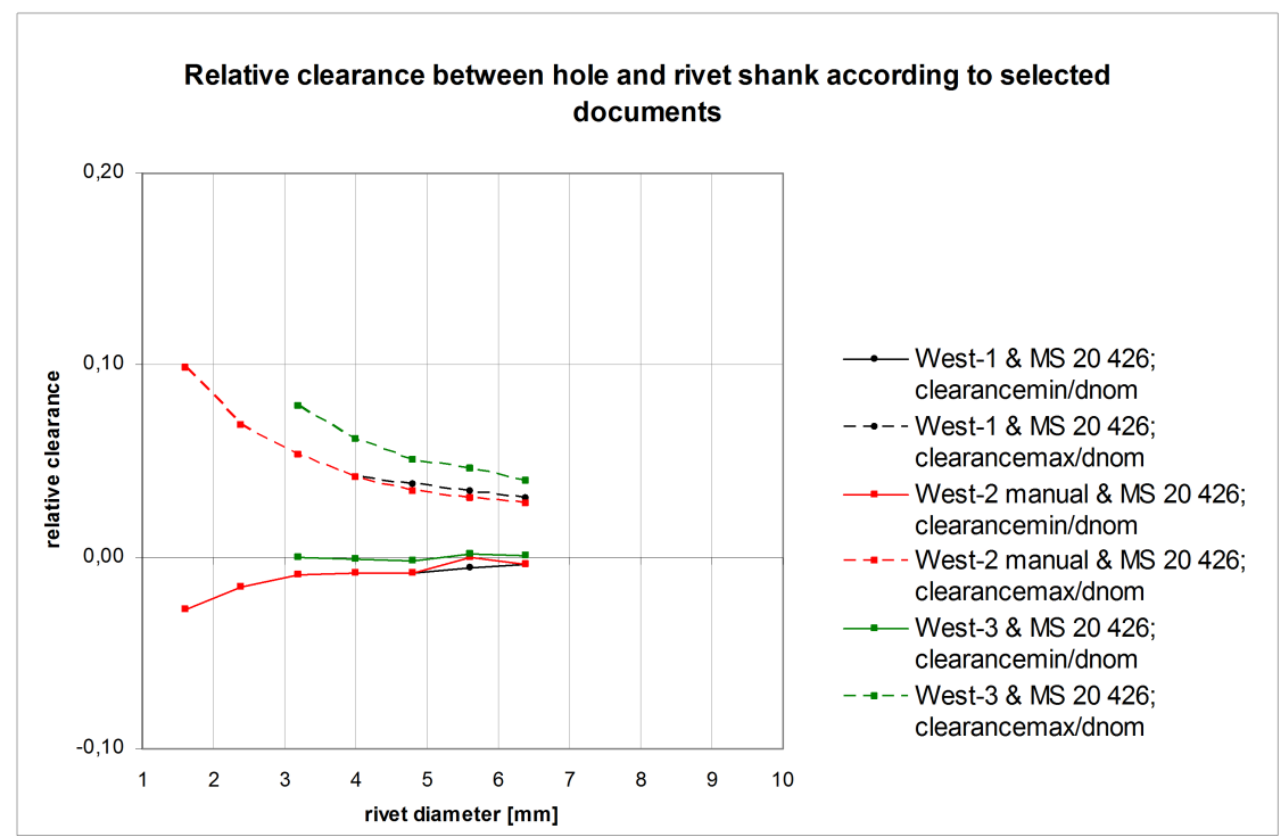

Fig. 29. Comparison of relative clearance (with regard to nominal rivet diameter) between the hole and rivet shank for three pairs:

- hole according to West-1 instruction - shank of a $100^{\circ}$ countersunk rivet NAS 1097, - hole according to West-2 instruction, manual riveting - shank of a $100^{\circ}$ countersunk rivet NAS 1097,

- hole according to West-3 instruction - shank of a 100' countersunk rivet NAS 1097. 
Of the western instructions, the West-3 instruction allows the largest clearances between a rivet shank and a rivet hole, Fig. 27. The Poland-1 instruction allows clearance slightly larger than the West-3. The Poland-2 instruction, in the case of a rivet with a compensator allows clearance slightly smaller than the West-1 instruction, Fig 16.

Relative clearances - clearances divided by nominal diameters of rivets - decrease as a rivet diameter increases.

\section{RIVET LENGTH SELECTION AND DRIVEN HEAD FORMATION}

The Polish industry standard BN-70/1120-03 recommends the following formula to select a rivet length:

$$
L=d+\frac{d_{0}}{d^{2}} \cdot S
$$

where

$\mathrm{d}$ - nominal rivet diameter,

$\mathrm{d}_{0}$ - maximum allowable hole diameter,

$\mathrm{S}$ - design grip length (thickness of sheet package).

The standard provides also a table (Table 5) which helps select a rivet length for the specific rivet diameter and a grip length.

In common engineering practice a simplified formula is used:

$$
L=S+1,2 \cdot d
$$

where

$\mathrm{L}$ - rivet length

$\mathrm{S}$ - grip length

1,2 - coefficient of a rivet shank length intended for a driven head formation

$\mathrm{d}$ - rivet diameter

If we present the results calculated with the formula (1) in a form of the formula (2), the coefficient of a rivet shank length intended for a driven head formation falls within the range of $1.05 \div 1.20$ (resulting from the formula (1), in the formula 2 this coefficient is constant and equal to 1,2). At the same time, this coefficient according to Table 2 in the BN-70/1120-03 standard (Table 5.), in the case of a rivet diameter larger or equal to $3 \mathrm{~mm}$ exceeds 1.3 and in the case of a diameter equal to $2 \mathrm{~mm}$, reaches as much as 1.6. 
Table 5. Rivet length selection according to the BN-70/1120-03 standard, Table 2

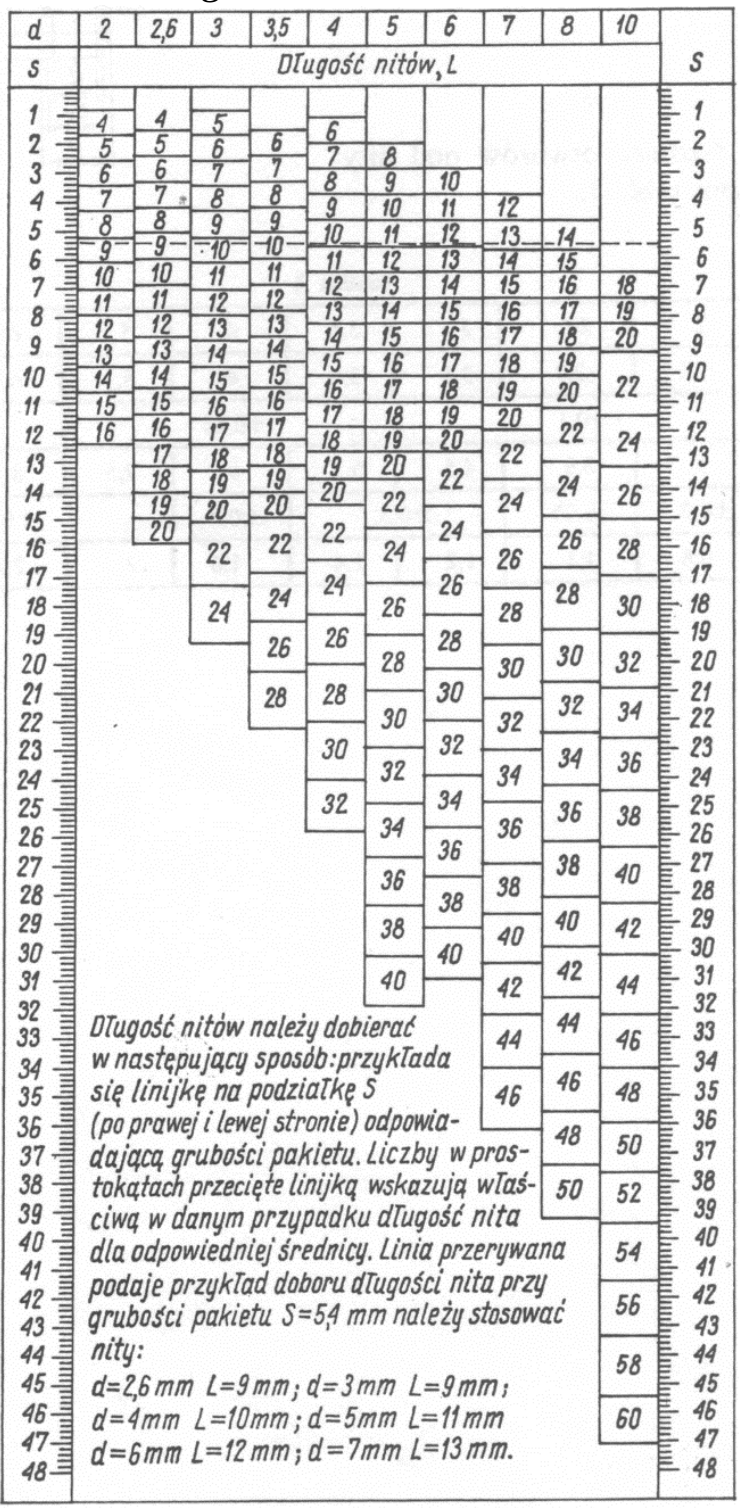

The formula for the rivet length selection provided by the West-3 instruction, similarly to the Poland-1 instruction, depends on a grip length and rivet diameter - Table 6.

Table 6. Rivet length selection according to West-3 instruction

\begin{tabular}{|c|c|}
\hline $\begin{array}{c}\text { Total thickness of sheets to } \\
\text { be riveted } \\
(\mathrm{S})\end{array}$ & Nominal length of rivet \\
\hline Up to $1.58 \mathrm{~mm}(1 / 16 ")$ & $L=S+d$ \\
\hline $\begin{array}{c}\text { Between } 1.58 \mathrm{~mm}(1 / 16 ") \\
\text { and } 12.7 \mathrm{~mm}(1 / 2 ")\end{array}$ & $\begin{array}{c}L=S+\frac{3}{2} \cdot d ; \\
\text { whichever is smaller }\end{array}$ \\
\hline Above $12.7(1 / 2 ")$ & $\begin{array}{c}L=1,07 \cdot S+\frac{3}{2} \cdot d ; \\
L=1,07 \cdot S+d+2,4[\mathrm{~mm}] \\
\text { whichever is smaller }\end{array}$ \\
\hline
\end{tabular}


The West-1 instruction provides a formula for the rivet length selection which depends on a grip length and a rive diameter, but also on a driven head shape - Table 7 .

Table 7. Rivet length selection according to West-1 instruction

\begin{tabular}{|c|c|c|c|c|}
\hline $\begin{array}{c}\text { Driven head } \\
\text { type }\end{array}$ & Conditions & $\begin{array}{c}\text { Nominal rivet } \\
\text { length }\end{array}$ & $\mathrm{d} \leq 4 \mathrm{~mm}$ & $L=S+1,5 \cdot d$ \\
\hline $\begin{array}{c}\text { Cylindrical } \\
\text { driven head }\end{array}$ & $\mathrm{d}>4 \mathrm{~mm}$ & $L=S+1,3 \cdot d$ & \\
\hline \multirow{2}{*}{$\begin{array}{c}\text { Countersunk } \\
\text { driven head }\end{array}$} & $\begin{array}{c}\text { countersink } \\
\text { formed in } 100^{\circ}\end{array}$ & $L=S+0,7 \cdot d$ & \\
\hline
\end{tabular}

In the West-2 instruction, diameters of solid rivets made of the materials: 2017-T4, 2017A-T4, 2117-T4, 3.1124-T4, 3.1324-T4 and 7050-T73 are obtained with the following formula:

$$
L=S+1,3 \cdot d
$$

At the same time, all western rivet standards recommend that the part of a rivet shank intended for a driven head formation have a length equal to 1.5 rivet diameter.

\section{DRIVEN HEAD FORMATION}

The Polish industry standard BN-70/1120-03 and riveting instructions Poland-1 and Poland-2 formulate identical requirements for a driven head: define the nominal diameter and positive and negative tolerances as well as the minimum height without any tolerances. At the same time, the Western manufacturing instructions provide maximum and minimum values of a driven head diameter and height. Fig. 30 presents comparison of driven head diameters according to the Polish industry standard BN-70/1120-1103 and the manufacturing instruction West-1, West-2 and West-3. 


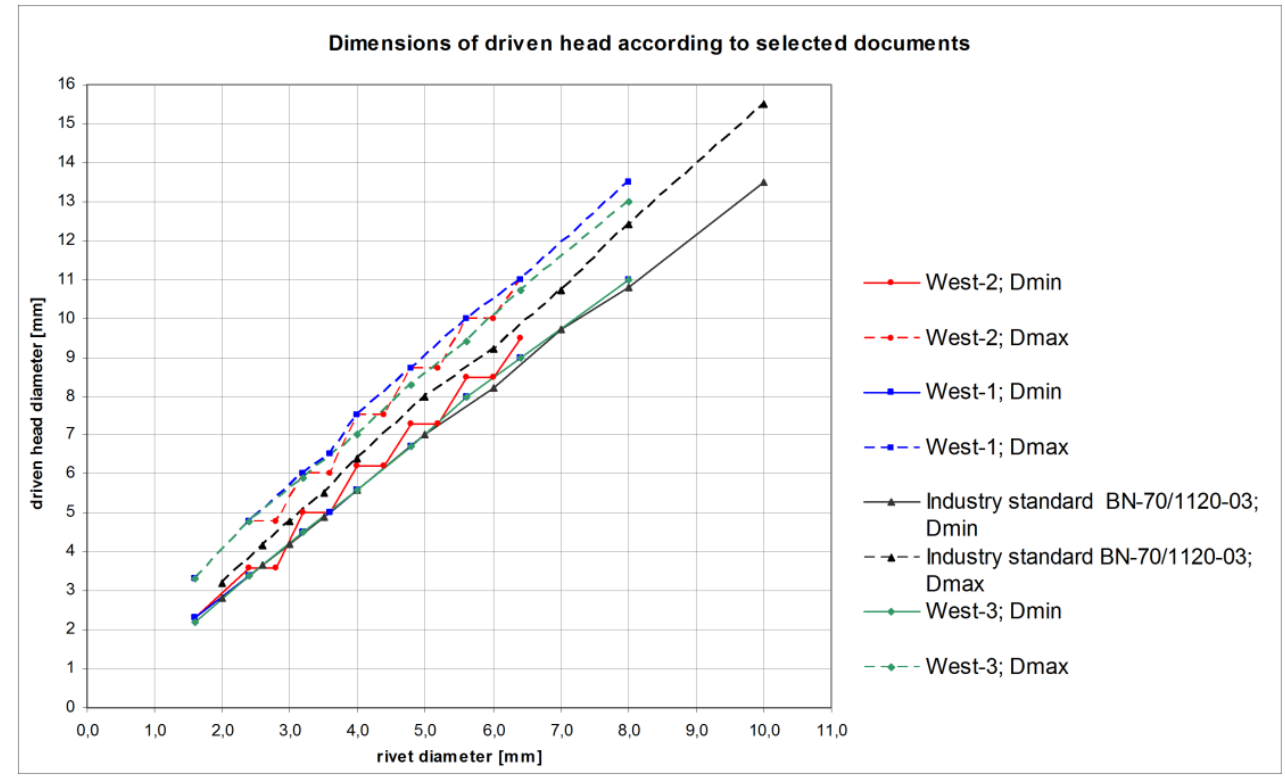

Fig. 30. Comparison of allowable driven head diameters according to Polish industry standard BN-70/1120-03 and manufacturing instructions West-1, West-2 and West-3.

Relative minimal and maximal diameters of driven heads (with regard to their nominal values) are presented in Fig. 31. It should be noted that the distances between surrounding curves decrease as the rivet diameter increases. The 'sawtoothed' shaped curve for the West- 2 instruction results from the introduction of the intermediate diameter of rivets (codes $3 \mathrm{X}, 4 \mathrm{X}, 5 \mathrm{X}, 6 \mathrm{X}$ and $7 \mathrm{X}$ ) probably for the purposes of repair - where the size of a driven head is the same as for rivets of the basic series (codes 3, 4 5, 6 and 7), which are intended to replaced. The minimal dimensions of a driven head in all instructions hover around $1.4 \mathrm{D} / \mathrm{d}$, while the maximal dimensions of a driven head are significantly higher in the western instructions.

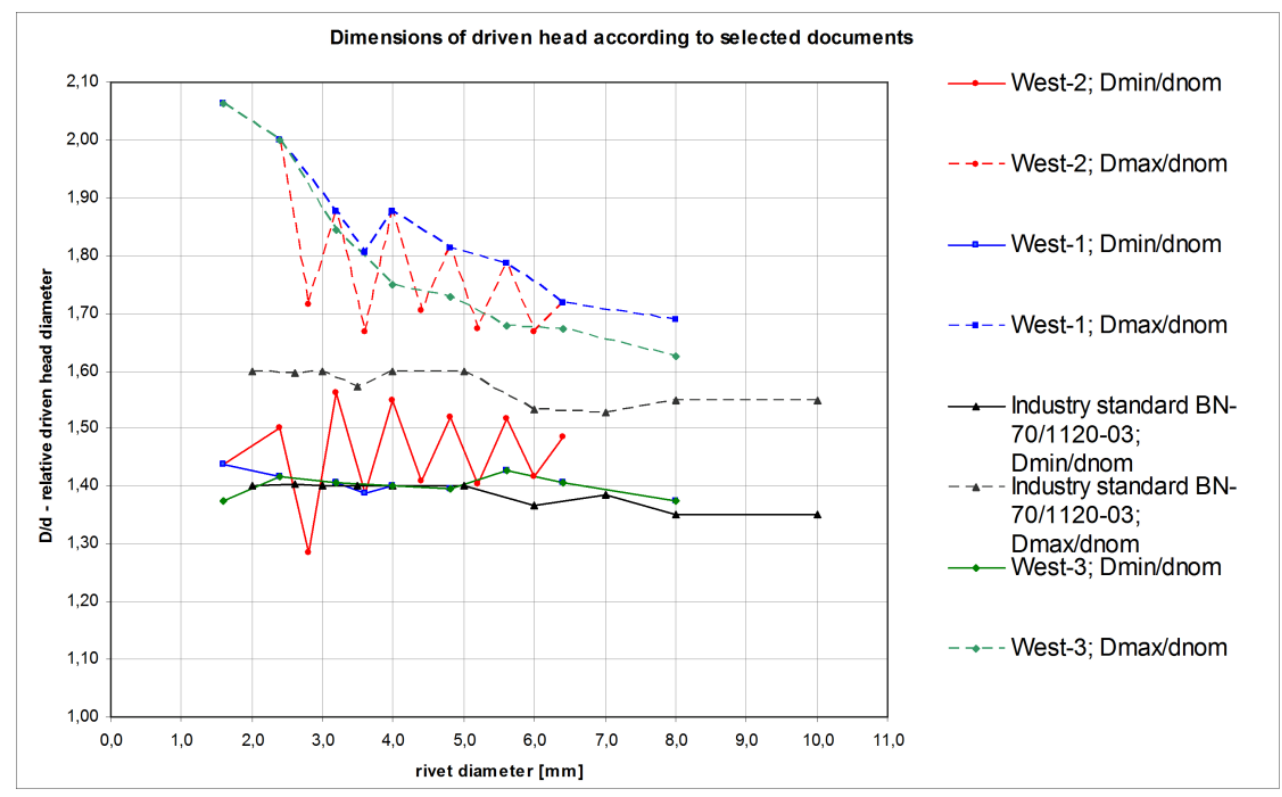

Fig. 31. Comparison of relative driven head diameters, allowable according to Polish industry standard BN-70/1120-03 and manufacturing instructions West-1, West-2 and West-3. 


\section{DISCUSSION AND CONCLUSIONS}

The use of high squeezing forces can cause driven heads to crack. This particularly concerns hard materials (used) for rivets. Müller [3] has pointed out that it appears in the case of rivets made of 7050-T73 alloy (designation - KE). The same effect is expected for rivets made of 2219-T81 alloy (designation - E). Rivets made of 2024 alloy (designation - DD, or D16 for its Russian counterpart) should be used in soft condition (Quenched Condition - AQ). Driven head cracking occurred during the realisation of the IMPERJA project [21] in the case of rivets made of the PA 25 alloy (Russian designation B65) and for D/d > 1.5, Fig. 32.
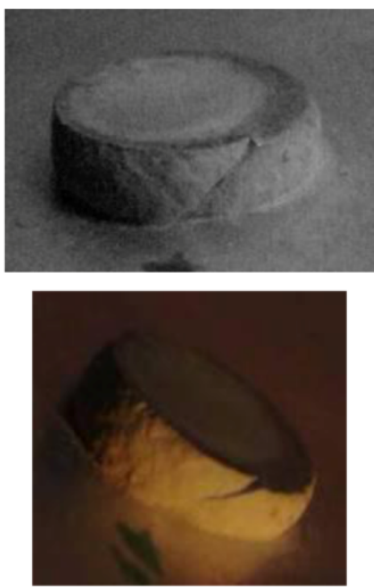
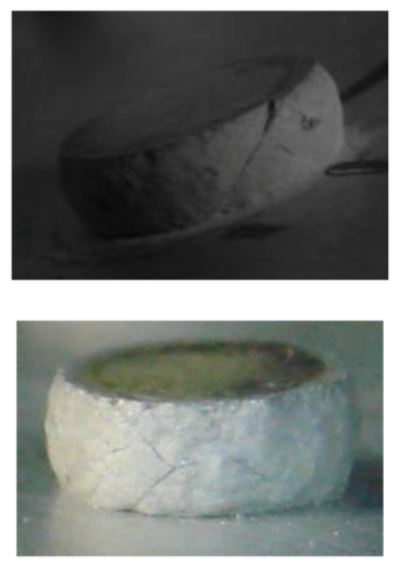
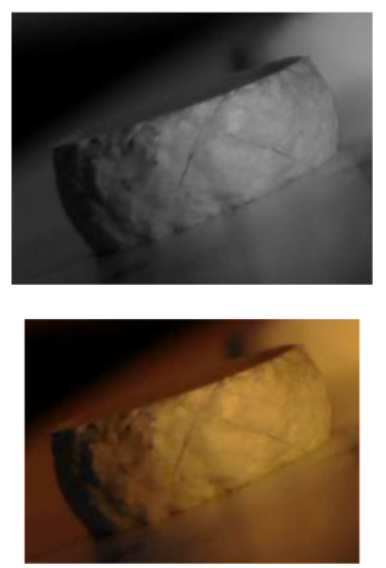
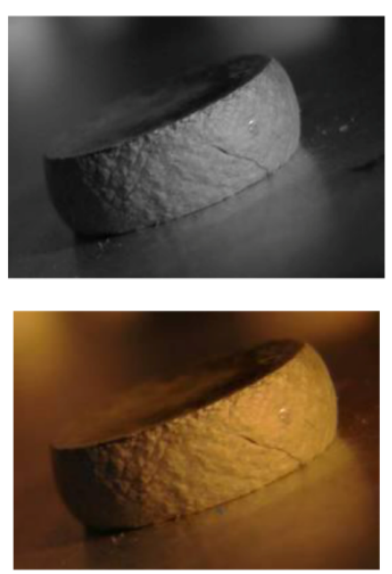

Fig. 32. Cracks in driven heads of rivets made of PA 25 alloy, recorded by IoA.

The use of high squeezing forces can also cause the sheets in between rivets to bulge. The aircraft technical specification defines the geometry accuracy of the wing and the empennage profile, on the other hand, the riveting instructions provide acceptable bulging of sheet. For example, the West-3 instruction states that the bulge has to be less than $0.3 \mathrm{~mm}$, the instruction West-1 that only $0.2 \mathrm{~mm}$ and the instruction Poland-1 admits the range of $0.2 \div 0.5 \mathrm{~mm}$, depending on the sheet thickness - higher values for smaller thickness.

Anodizing of rivets - used to protect rivets from corrosion - reduces the fatigue life of an airframe. During riveting, an anodized layer is crushed - hard mini-lumps are formed which are deposited between the rivet and the elements joined. This causes fatigue crack initiation to accelerate.

Of the western instructions, the largest clearances are allowed by the West- 3 instruction. The Poland-1 instruction allows clearance slightly larger than the West-3, while the Poland-2 in the case of the rivet with a compensator allows clearance slightly smaller than the one defined in the West-1 instruction.

Generally, the western riveting instructions have the following characteristic features:

a) smaller clearance between a rivet shank and a hole.

b) higher squeezing force.

c) chamfer or filet at an edge between a countersink and a cylindrical part of a rivet hole.

Based on the experience from the IMPERJA project [21] it can be qualitatively concluded that the above factors enhance the fatigue life of riveted joints. A quantitative assessment requires carrying out detailed analyses (e.g. using FEM) and further research. 


\section{REFERENCES}

1. Grogoriew W., Goldowski P.: Riveting of Al alloy structures. Ministry of National Defence Publishing, Warsaw, 1957, 1. edition. (in Polish)

2. Military Specification. Rivets, buck type, preparation for and installation of. 1977. http://www.rivetbangers.com/documents/MIL-R-47196A_MI.pdf

3. Müller R. P. G.: An Experimental Investigation on the Fatigue Behavior of Fuselage Riveted Lap Joints; The Significance of the Rivet Squeeze Force, and a Comparison of 2924-T3 and Glare 3. Doctor thesis, Delft University of Technology, Faculty of Aerospace Engineering, Structures and Materials Laboratory, Printed in Netherlands by Universitatdrukkerij, Delft, ISBN 90-9008777-X, October 1995.

4. Rans Calvin D., The Role of Rivet Installation on the Fatigue Performance of Riveted Lap Joints. Doctor thesis, Carleton University, Ottawa, Ontario, Canada, August 2007.

5. de Rijk J.J.M: Analysis of Fatigue in Mechanically Fastened Joint. An analytical and experimental investigation. Doctor thesis, Delft University of Technology, Faculty of Aerospace Engineering, Structures and Materials Laboratory, Printed in Netherlands by Universitatdrukkerij, Delft University Press Science, Delft, ISBN 90-407-2590-X, June 2005.

6. Polish industry standard BN-70/1120-03: Rivets for aviation-related purposes. Length selection, driven heads dimensions and diameters of rivets holes. (in Polish)

7. Polish industry Standards BN-70/1121-0X. Rivets with head:, flat -01 , round $-03,90^{\circ}$ countersunk $-04,120^{\circ}$ countersunk -05, brazier -06. (in Polish)

8. Russian standard OST 1 34040-79. Brazier rivet with a compensator.

9. $90^{\circ}$ countersunk rivet with a compensator ANU 0301.

10. Russian standard OST 1 12020-75. 90 countersunk rivet with a compensator.

11. Process specification Poland-1. (in Polish)

12. Process specification Poland-2. (in Polish)

13. MS 20 426. Rivet, solid, countersunk 100', precision head, aluminum and titanium, columbium alloy.

14. NAS 1097. Rivet, solid, $100^{\circ}$, flush shear head, aluminum alloy, titanium, columbium alloy.

15. MS 20 470. Rivet, solid, universal head, aluminum alloy, titanium, columbium alloy.

16. West-3. Process specification. Installation of solid Rivets.

17. West-1. Process specification. Installation of solid Rivets.

18. West-2. Process specification. Installation of solid Rivets.

19. West-4. Process specification. Drilling, reaming and countersinking of rivet and screw holes.

20. Polish standard. Aerospace series - Rivet, $100^{\circ}$ reduced flush head, close tolerance - Inch series, PN-EN-6069:2010.

21. Kaniowski J. (2012). The Synthetic Description of the Results, Scientific Achievements and Practical Application of the Eureka-IMPERJA Project, E3496!, titled "Improving the Fatigue Performance of Riveted Joints in Airframes. A. Niepokólczycki (Ed.). Fatigue of Aircraft Structures, Monographic Series, ISSUE 2012, pp.38-57. ISSN 2081-7738. Institute of Aviation Scientific Publication, Warsaw, Poland.

http://www.degruyter.com/view/j/fas.2012.1.issue-4/v10164-012-0055-4/v10164-012-00554.xml?format=INT, DOI: 10.2478/v10164-012-0055-4, April 2013.

22. Wronicz W., Kaniowski J.: The Analysis of the Influence of Riveting Parameters Specified in Selected Riveting Instructions on Residual Stresses. A. Niepokólczycki (Ed.). Fatigue of Aircraft Structures, Monographic Series, ISSUE 2014. Institute of Aviation Scientific Publication, Warsaw, Poland. 